\title{
Mechanotransduction is a context-dependent activator of TGF- $\beta$ signaling in mesenchymal stem cells
}

Citation for published version (APA):

Vermeulen, S., Roumans, N., Honig, F., Carlier, A., Hebels, D. G. A. J., Eren, A. D., Dijke, P. T., Vasilevich, A., \& de Boer, J. (2020). Mechanotransduction is a context-dependent activator of TGF- $\beta$ signaling in mesenchymal stem cells. Biomaterials, 259, [120331]. https://doi.org/10.1016/j.biomaterials.2020.120331

Document status and date:

Published: 01/11/2020

DOI:

10.1016/j.biomaterials.2020.120331

Document Version:

Publisher's PDF, also known as Version of record

Document license:
Taverne

\section{Please check the document version of this publication:}

- A submitted manuscript is the version of the article upon submission and before peer-review. There can be important differences between the submitted version and the official published version of record.

People interested in the research are advised to contact the author for the final version of the publication, or visit the DOI to the publisher's website.

- The final author version and the galley proof are versions of the publication after peer review.

- The final published version features the final layout of the paper including the volume, issue and page numbers.

Link to publication

\footnotetext{
General rights rights.

- You may freely distribute the URL identifying the publication in the public portal. please follow below link for the End User Agreement:

www.umlib.nl/taverne-license

Take down policy

If you believe that this document breaches copyright please contact us at:

repository@maastrichtuniversity.nl

providing details and we will investigate your claim.
}

Copyright and moral rights for the publications made accessible in the public portal are retained by the authors and/or other copyright owners and it is a condition of accessing publications that users recognise and abide by the legal requirements associated with these

- Users may download and print one copy of any publication from the public portal for the purpose of private study or research.

- You may not further distribute the material or use it for any profit-making activity or commercial gain

If the publication is distributed under the terms of Article $25 \mathrm{fa}$ of the Dutch Copyright Act, indicated by the "Taverne" license above, 


\title{
Mechanotransduction is a context-dependent activator of TGF- $\beta$ signaling in mesenchymal stem cells
}

\author{
Steven Vermeulen $^{\mathrm{a}, \mathrm{b}}$, Nadia Roumans ${ }^{\mathrm{a}}$, Floris Honig ${ }^{\mathrm{a}}$, Aurélie Carlier ${ }^{\mathrm{a}}$, Dennie G.A.J. Hebels ${ }^{\mathrm{a}}$, \\ Aysegul Dede Eren ${ }^{\mathrm{a}, \mathrm{b}}$, Peter ten Dijke ${ }^{\mathrm{c}}$, Aliaksei Vasilevich ${ }^{\mathrm{b}}$, Jan de Boer ${ }^{\mathrm{b}, *}$

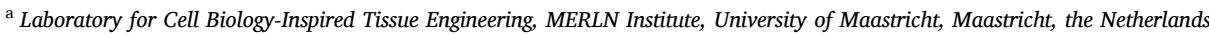 \\ ${ }^{\mathrm{b}}$ BioInterface Science Group, Department of Biomedical Engineering and Institute for Complex Molecular Systems, University of Eindhoven, Eindhoven, the Netherlands

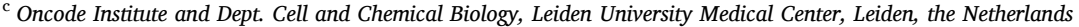

\section{A R T I C L E I N F O}

\section{Keywords:}

Actin dynamics

Biomaterials

Mesenchymal stem cells

Scleraxis

Mechanobiology

TGF- $\beta$

\begin{abstract}
A B S T R A C T
We previously found that surface topographies induce the expression of the Scxa gene, encoding Scleraxis in tenocytes. Because $S c x a$ is a TGF- $\beta$ responsive gene, we investigated the link between mechanotransduction and TGF- $\beta$ signaling. We discovered that mesenchymal stem cells exposed to both micro-topographies and TGF- $\beta 2$ display synergistic induction of SMAD phosphorylation and transcription of the TGF- $\beta$ target genes SCX, $a$-SMA, and SOX9. Pharmacological perturbations revealed that Rho/ROCK/SRF signaling is required for this synergistic response. We further found an activation of the early response genes $S R F$ and EGR1 during the early adaptation phase on micro-topographies, which coincided with higher expression of the TGF- $\beta$ type-II receptor gene. Of interest, PKC activators Prostratin and Ingenol-3, known for inducing actin reorganization and activation of serum response elements, were able to mimic the topography-induced TGF- $\beta$ response. These findings provide novel insights into the convergence of mechanobiology and TGF- $\beta$ signaling, which can lead to improved culture protocols and therapeutic applications.
\end{abstract}

\section{Introduction}

Under physiological conditions, tissue homeostasis is maintained by the appropriate spatio-temporal responses of cells to environmental signals, such as secreted cytokines and transmembrane proteins from adjacent cells, but also by mechanical forces and changes in cell shape [1]. The latter is evident by the secretion and autocrine activity of insulin-like growth factor (IGF) by myocytes upon mechanical stimulation, a potent growth factor that induces muscle growth [2]. Similarly, tendon tissue homeostasis and growth depends on both mechanical forces [3] and transforming growth factor (TGF- $\beta$ ) signaling [4]. Also, the myofibroblastic state during tissue repair depends both on the mechanical characteristics of the matrix environment as well as the presence of TGF- $\beta$ [5]. During embryonic development, mechanical forces are essential for proper morphogenesis in conjunction with biochemical signals, as shown by the spatial reorganization of TGF- $\beta$ receptors upon cell confinement in gastruloids [6]. Mechanical forces can rapidly activate various intracellular signaling pathways [7]. Well-documented examples include the activation of the transcription factors yes-associated protein 1 (YAP), and transcriptional coactivator with PDZ-binding motif (TAZ) through stretching [8] and cell shape changes [9]. These transcription factors are essential for tissue homeostasis and embryogenic processes [10,11], such as osteogenesis [12], which is also influenced by bone morphogenetic protein 2 (BMP-2) [13]. Changes in actin dynamics influence serum response factor (SRF) activity through altered binding with co-transcription factors [14], leading to broad changes in physiological processes $[15,16]$, including myofibroblast differentiation [17] which in turn can be regulated through TGF- $\beta$ signaling [18]. How these mechanical and biochemical signals converge to drive cell behavior is poorly understood. Therefore, gaining novel insights in these mechanisms is vital for developing therapeutics in case of improper cell function and tissue engineering applications.

Since it is difficult to decouple the effects of biochemical and mechanical stimuli in vivo, essential insights are gained by in vitro experiments. Here, physical cues relayed through altered surface geometry can offer mechanical stimulation through changing cell shape. Cell geometry profoundly affects cell behavior, as shown by altering the lineage specification of stem cells [19-21]. Evidence exists that cell geometry

\footnotetext{
* Corresponding author.

E-mail address: j.d.boer@tue.nl (J. de Boer).
} 
also influences the biological effects of soluble factors. For example, adhesive islands alter the genomic response after tumor necrosis factor (TNF) $\alpha$ stimulation [22], and growth factor signaling from BMP-2 [23] or serum [24]. Also, cell confinement through micro-wells reduces the inflammatory response to lipopolysaccharide (LPS) in macrophages [25]. Of interest here is that surprisingly little is known how surface topography controls the cell's response towards growth factor signaling. This is an important consideration since growth factors are involved in numerous biological processes, including differentiation [26] and maintenance of phenotypic identity [27]. Research involving cell stretching hints towards an interesting interplay between biomechanical forces and soluble factors. For example, cell stretching increases the sensitivity for soluble factors through altering receptor expression or activity [28-30]. In this manuscript, we provide new insights in this field by demonstrating that topographical cues alter the response of mesenchymal stem cells (MSCs) to TGF- $\beta$ signaling.

\section{Results}

2.1. MSCs cultured on micro-topographies display altered actin dynamics and differential expression of cytoskeletal genes

An eye-catching characteristic of cells cultured on surface structures are profound changes in cell morphology [21,31]. This is demonstrated
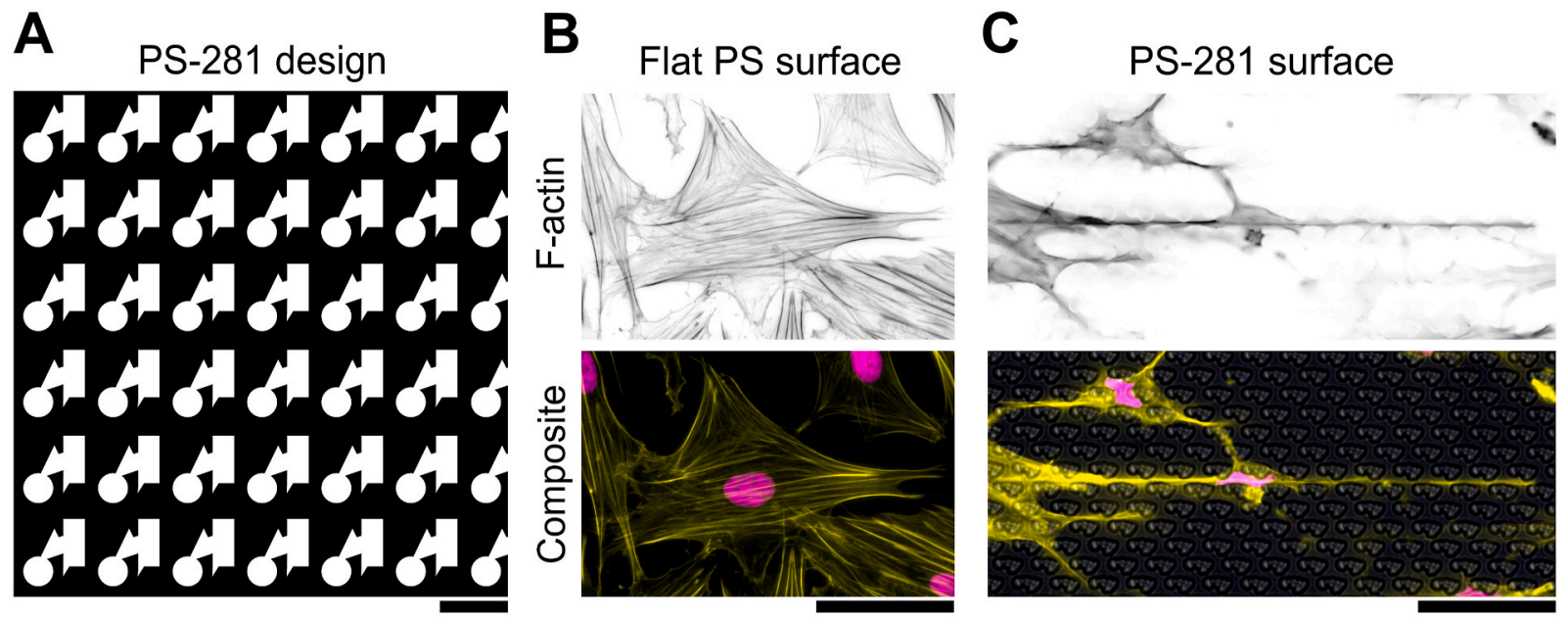

D

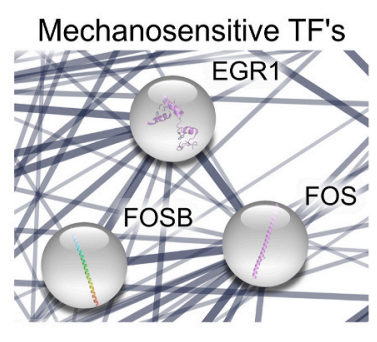

E

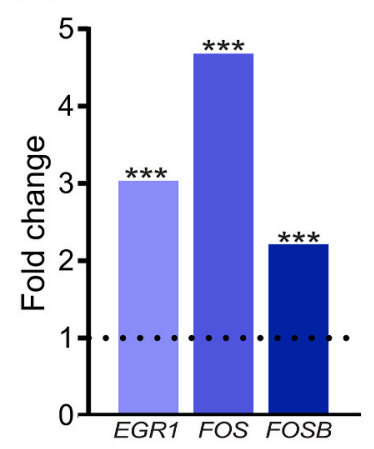

$\mathbf{F}$

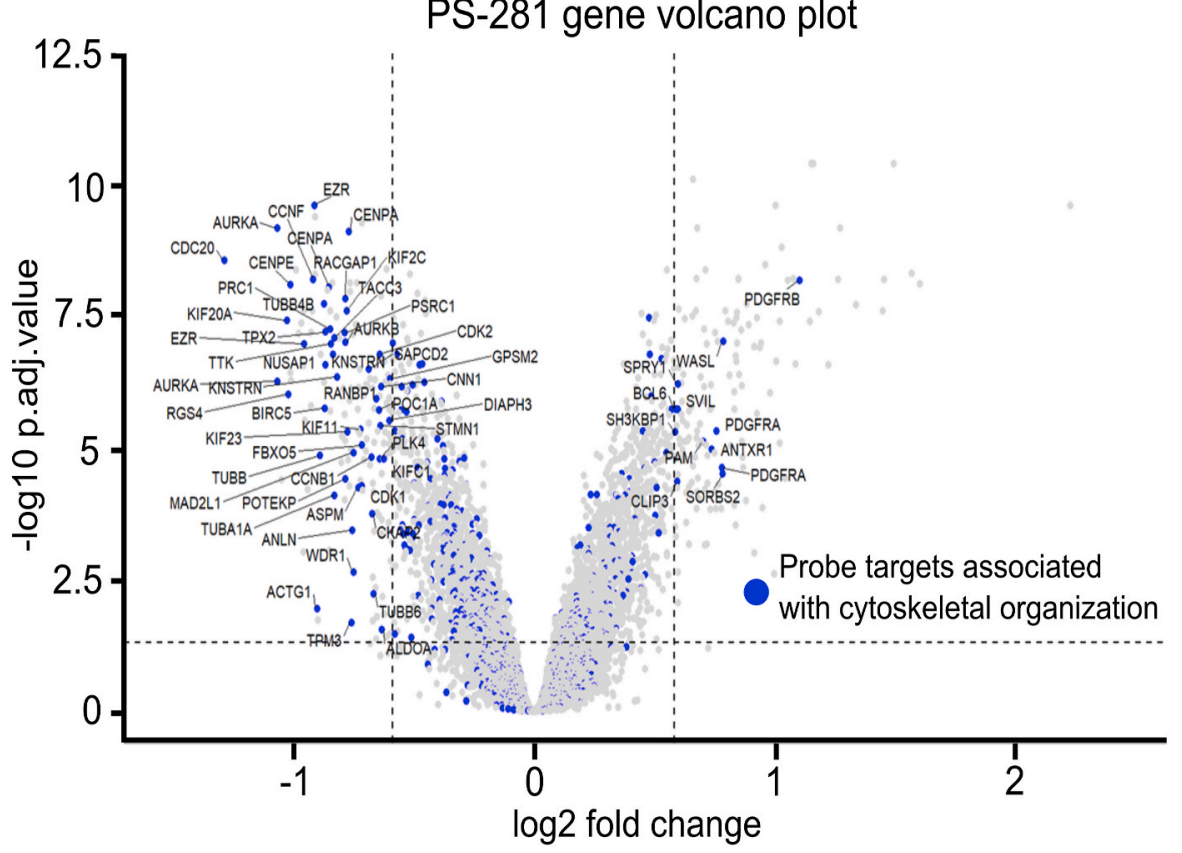

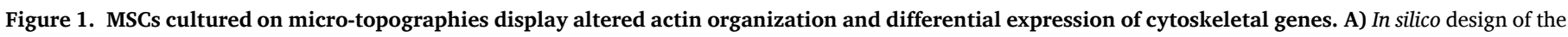

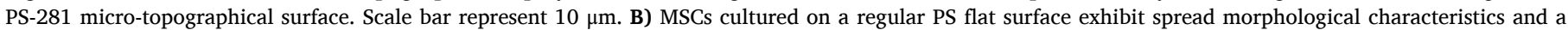

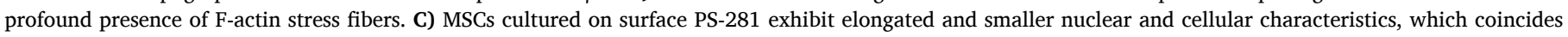

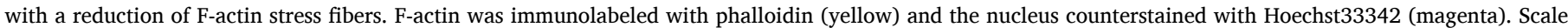

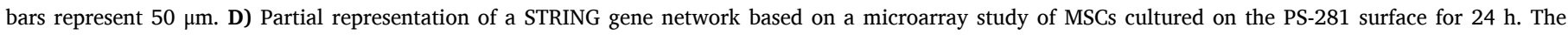

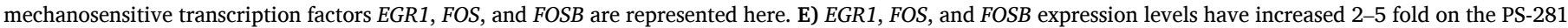

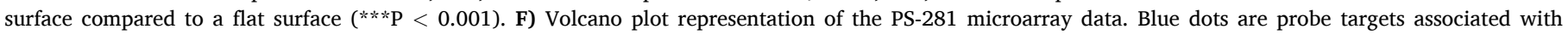

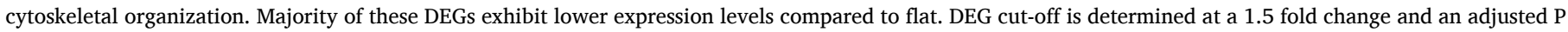
value of 0.05 . 
when seeding adipose-derived MSCs on micro-topography PS-281, which is a geometrically designed surface structure of $10 \mu \mathrm{m}$ height and length along its longest axis (Fig. 1A and Supplementary Fig. 1). After $24 \mathrm{~h}$ of cell culture, these micro-topographies greatly reduce the cell and nuclei size of MSCs compared to a standard flat surface culture (Fig. 1B and C). Furthermore, these changes in morphology are accompanied by a reduction of filamentous(F)-actin stress fibers, with the cytoskeleton obtaining elongated characteristics in between the structures. We previously assessed the transcriptome of bone marrow-derived MSCs on surface PS-281 relative to MSCs on flat control surfaces (under review) and produced a STRING protein-protein interaction network with 248 nodes and 1839 edges based on differentially expressed genes (DEGs) with a fold change higher than 1.5, lower than -1.5 , and an adjusted p-value smaller than 0.05 . To assess how micro-topographies elicit a biomechanical response, we screened the DEGs for mechanosensitive transcription factors and found an upregulation of early growth response gene 1 (EGR1) (3.0 fold change), FBJ murine osteosarcoma viral oncogene homolog (FOS) (4.7 fold change), and FOSB (2.2 fold change) (Fig. 1D and E) [32]. We next produced a volcano plot of genes with Gene Ontology (GO) term "cytoskeleton organization", and noticed that many cytoskeleton related DEGs exhibit lower expression when cultured on surface PS-281, with a total of 48 DEGs downregulated and 11 DEGs upregulated (Fig. 1F and Supplementary Tables 1-2). Downregulated genes are involved in microtubule dynamics, e.g., stathmin 1 (STMN1; -1.6 fold change), an important cytoskeletal effector regulating microtubule dynamics [33], tubulin $\beta$ class I (TUBB; -1.9 fold change), tubulin $\beta$ 4B class IVb (TUBB4B; -1.8 fold change), tubulin $\alpha 1 \mathrm{a}$ (TUBA1A; -1.8 fold change), and tubulin $\beta 6$ class V (TUBB6; -1.6 fold change). Other genes such as actin $\gamma-1$ (ACTG1; -1.9 fold change) and tropomyosin 3 (TPM3; -1.7 fold change) form integral parts of the cytoskeleton [34]. Of interest, we also observed a slight downregulation of actin $\beta$ (ACTB; -1.3 fold change). We further found a reduction in expression levels of genes associated with small GTPase rho signal transduction and subsequent cytoskeletal organization [35] (Supplementary Fig. 2). For example, we detected a downregulation of ezrin (EZR; -1.9 fold change), an actin-binding protein that acts as a linker between the actin cytoskeleton and plasma membrane proteins [36], and positively modulates rho signaling through the interaction with rho GDP dissociation inhibitors [37]. A downregulation was observed for diaphanous related formin 3 (DIAPH3; -1.5 fold change), which is required for F-actin stress fiber formation [38] and regulates SRF activity [39]. We also mention the downregulation of anillin actin-binding protein ( $A N L N ;-1.7$ fold change), which is important for cytoskeletal dynamics [40] and is involved in rho signaling [41]. The gene signature induced by surface PS-281 demonstrates that the cytoskeleton is under a lot of change $24 \mathrm{~h}$ after cell seeding, which corresponds with the visual observed alterations in cytoskeleton architecture and cell geometry.

\subsection{Activation of early response genes is associated with early actin reorganization}

Based on the observed increased expression of FOS and EGR 1 at $24 \mathrm{~h}$, we decided to investigate actin organization dynamics and the expression of early genes and proteins with a known relation to actin remodeling on surface PS-1018, which we previously discovered as a surface that induces Scleraxis ( $S c x$ ), and EGR1 expression in tenocytes [42]. Furthermore, PS-1018 can be manufactured in a $100 \mathrm{~mm}$ dish format for each fabricated sheet, which is not the case for surface PS-281 that only could be manufactured in $15 \mathrm{~mm}$ format, thereby facilitating further experiments. Analogous as surface PS-281, PS-1018 has a height profile of $10 \mu \mathrm{m}$, yet differs in size with a $20 \mu \mathrm{m}$ length along its longest axis. Surface PS-1018 (Fig. 2A and Supplementary Fig. 3) induced cell elongation with a profound reduction in cell and nuclear size, while reducing actin stress fibers (Fig. 2B), similar to surface PS-281. As early as $1 \mathrm{~h}$ after cell seeding, we noted that cells on flat surfaces exhibited a diffuse actin pattern with a round cell morphology (Fig. 2C); however, MSCs adhering on the surface PS-1018 displayed different dynamics. Here, MSCs engulfed the micro-topographies with concentrated F-actin stress fiber formation on top of the structures (Fig. 2D), but a more diffuse actin pattern at the bottom and in between the structures (Fig. 2E). Quantification of F-actin levels showed significantly elevated F-actin levels at $1 \mathrm{~h}$ and $2 \mathrm{~h}$ on PS-1018, with levels peaking at $1 \mathrm{~h}$ and dropping afterwards (Supplementary Figs. 4A-B). To probe the early regulatory responses, we exposed MSCs cultured for $2 \mathrm{~h}$ to flat and surface PS-1018 and analyzed the phospho-proteome by mass spectrometry (Supplementary Fig. 5). We detected increased levels of phosphorylated actin in cells cultured on surface PS-1018, indicating active cytoskeletal reorganization $[43,44]$. Also, we detected increased levels of phosphorylated adenylyl cyclase-associated protein 1 (CAP-1) and drebrin 1 (DBN1), which regulate actin dynamics $[45,46]$. These observations indicate that MSCs cultured on the micro-topography are subjected to dynamic cytoskeletal regulation, characterized by an early adaptation phase involving actin remodeling.

We next investigated genes and proteins, of which it is known that their expression or activity is influenced by actin. First, we observed a 3.6 fold increase in EGR1 mRNA levels compared to flat at $24 \mathrm{~h}$ and no significant difference at $48 \mathrm{~h}$ (Fig. 2F). At earlier time points, we assessed EGR1 protein expression dynamics on both flat and PS-1018 (Fig. 2G). At $2 \mathrm{~h}$, we found increased EGR1 levels in the nucleus when MSCs are cultured on PS-1018 compared to flat (Fig. 2H). Of interest, we measured a slight yet non-significant increase at $24 \mathrm{~h}$. This seemingly contradicts the qPCR and microarray observations on surface PS-281; however, we believe this to be caused by a subpopulation of cells with high EGR1 levels on the PS-1018 surface that skews the global EGR1 levels measured on RNA level. Equally interesting was the observation that after $2 \mathrm{~h}$, EGR1 levels on a flat surface was higher than on flat and the PS-1018 surface at $24 \mathrm{~h}$. We contribute this phenomenon to cellseeding that induces a biomechanical response.

Next, we explored if we could detect alterations in SRF levels after 2 $\mathrm{h}$ and $24 \mathrm{~h}$ on PS-1018 (Fig. 2I). SRF is an important transcription factor that is associated with changes in actin dynamics [41] and known for inducing transcription of genes with serum response elements in its promoter, which includes FOS, EGR1, and SRF itself $[47,48]$. Similar to EGR1, high intensities of nuclear SRF were observed at $2 \mathrm{~h}$ (Fig. 2J), followed by a slight yet non-significant decrease at $24 \mathrm{~h}$ compared to the flat surface.

\subsection{Micro-topographical cues elevate TGF- $\beta$ R-II and SCX levels in MSCs}

EGR1 elevation on surface PS-1018 is interesting, considering that EGR1 is involved in the expression of the tendon-specific transcription factor scleraxis $(S C X)[49,50]$, which in previous work was induced in tenocytes on micro-topographies [42]. It is unclear how EGR1 influences SCX but considering that SCX is upregulated in response to TGF- $\beta$ [26], evidence exists that this is through increased expression of the TGF- $\beta 2$ ligand [51] or the transforming growth factor- $\beta$ type II receptor (TGF- $\beta$ R-II) [52]. Browsing of the PS-281 transcriptomics data set for TGF- $\beta$ signaling revealed five genes with a significant fold change of more than 1.5 associated with GO biological process "Response to TGF- $\beta$ " (Fig. 3A). These include the previously mentioned FOS gene (4.6 fold change), known for participating with small mothers against decapentaplegic (SMAD) proteins to influence TGF- $\beta$ signaling [53]. Also, an upregulation was observed for the TGF- $\beta$ inducible genes collagen-III (COL-III; 1.6 fold change) [54], prostate transmembrane protein androgen-induced 1 (PMEPA1; 1.5 fold change) [55], and matrix remodeling-associated protein 5 (MXRA5; 1.5 fold change) [56]. We also noted a downregulation of neuronal regeneration related protein (NREP; -1.5 fold change), which is related to an expression decrease of the growth factors TGF- $\beta 1$ and TGF- $\beta 2$ [57]. In addition, we noticed an increase in $S M A D 7$ expression (1.41 fold change), an antagonist of the TGF- $\beta$ /SMAD pathway that functions as a negative feedback activator after TGF- $\beta$ signaling [58]. We also mention a 2.81 fold change increase 
A

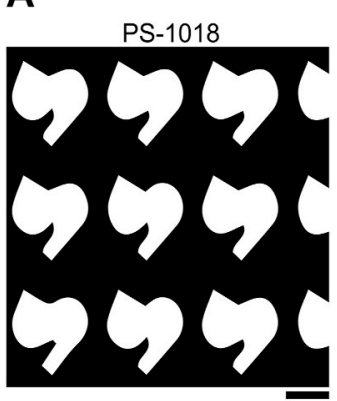

$\mathbf{F}$

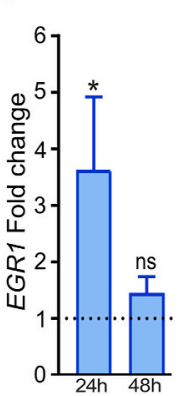

G
B
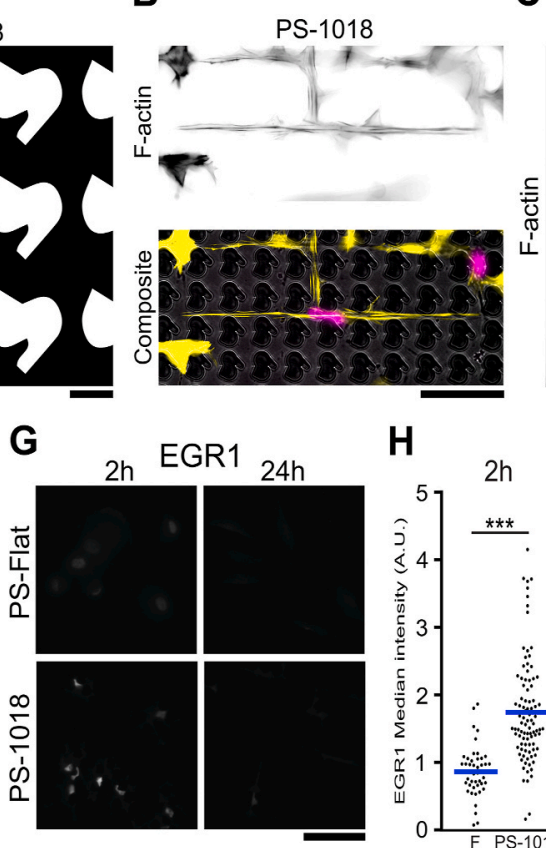

$\mathrm{H}$

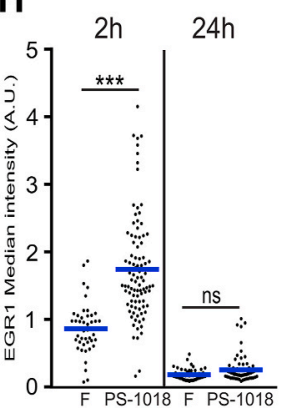

D

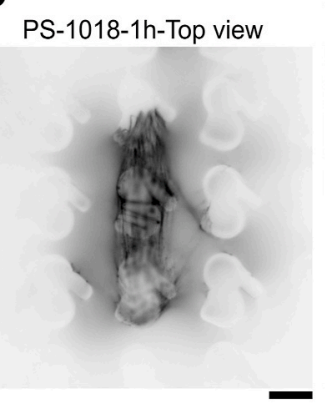

$E$

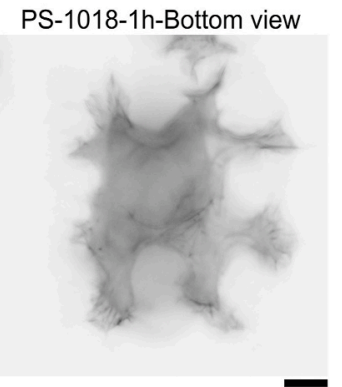

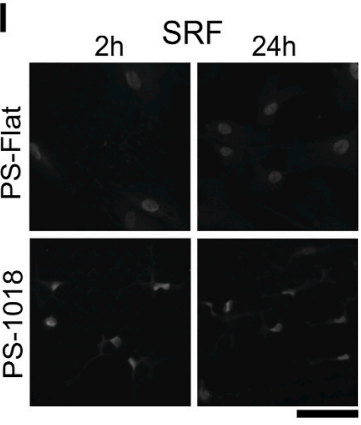

J

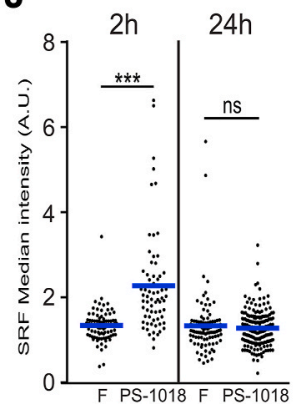

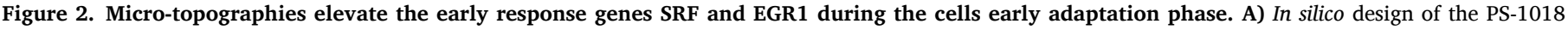

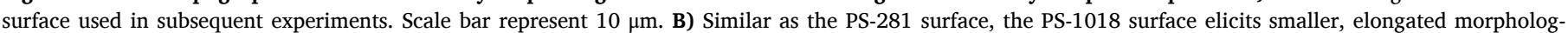

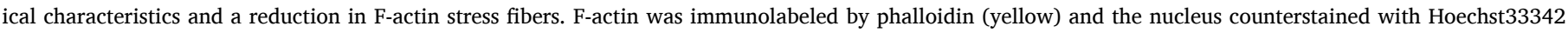

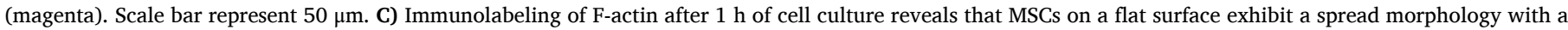

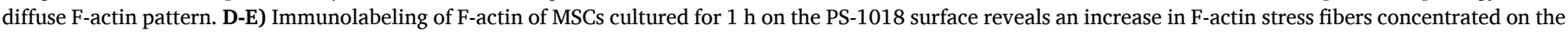

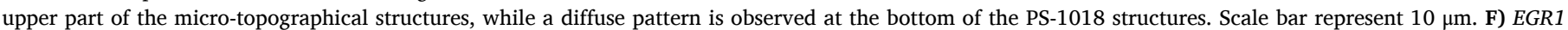

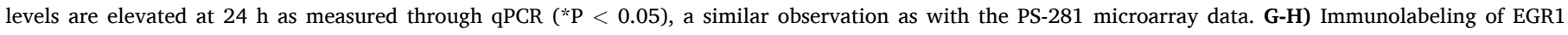

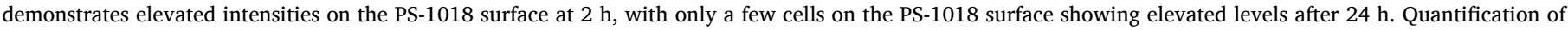

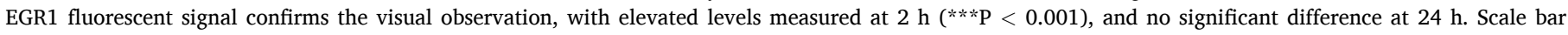

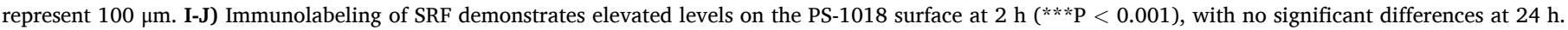

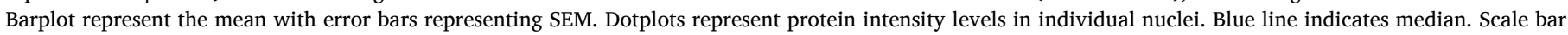
represent $100 \mu \mathrm{m}$.

of VCAM1, which is TGF- $\beta$ inducible [59], yet was not part of the GO list.

Of interest, we also noted (through multiple probes) an upregulation of TGF- $\beta R-I I$ (1.9 and 2.0 fold change), an essential component of the TGF- $\beta$ /SMAD signaling pathway. These findings strengthen the hypothesis that micro-topographies sensitize MSCs for TGF- $\beta$ related signaling. We confirmed increased TGF- $\beta R$-II expression on surface PS1018 by qPCR after $8 \mathrm{~h}$ (Fig. 3B; 1.3 fold change), and reaching a maximum at $24 \mathrm{~h}$ ( 2.1 fold change). At $48 \mathrm{~h}$, no significant differences in $T G F-\beta R$-II levels were detected between PS-1018 and flat. It is known that mitogen-activated protein kinase kinase (MEK) inhibitors, such as U0216, can inhibit the activation of its downstream target EGR1 [60, 61], which we experimentally verified (Supplementary Fig. 6). Interestingly, U0216 also decreased TGF- $\beta$ R-II expression on the PS-1018 surface.

We further observed a 2.5 fold increase of the TGF- $\beta$ inducible gene $S C X$ after $8 \mathrm{~h}$, with maximum SCX levels after $24 \mathrm{~h}$ (3.5 fold change), which decreased to 2.8 fold after $48 \mathrm{~h}$. After $72 \mathrm{~h}$, no significant SCX elevation was detected (Fig. 3C). We also found that U0216 reduced topography-induced $S C X$ upregulation. These findings demonstrate that micro-topographies enhance $S C X$ levels in MSCs, which could be guided by a general sensitization for TGF- $\beta$ signaling through SRF, EGR1 and TGF-pR-II (Fig. 3D).

\subsection{Surface topography and TGF- $\beta 2$ synergistically induce TGF- $\beta$ target genes}

Given that $S C X$ can be induced by both TGF- $\beta 2$ [26] and topography [42], we investigated the combined effect of TGF- $\beta 2$ and micro-topographies on TGF- $\beta$ signaling. First, we measured SMAD2/3 phosphorylation (P-SMAD) as an immediate response to TGF- $\beta$ receptor signaling and mediator of TGF- $\beta$ target gene expression. $24 \mathrm{~h}$ time after cell seeding, the timepoint with maximum TGF- $\beta$ R-II expression, we exposed MSCs to TGF- $\beta 2$ and fixed the cells $30 \mathrm{~min}$ after the treatment (Fig. 4A). Quantification of nuclear P-SMAD levels demonstrated that TGF- $\beta 2$ treatment resulted in a 1.2 fold increase in nuclear P-SMAD levels compared to cells cultured on flat (Fig. 4B). Of interest, we observed that TGF- $\beta 2$ treatment of MSCs grown on PS-1018 resulted in a 1.7-fold increase in nuclear P-SMAD levels compared to non-treated cells. Next, we isolated the RNA of MSCs cultured on flat or PS-1018, treated with and without TGF- $\beta 2$ between $4 \mathrm{~h}$ and seven days after cell seeding (Fig. 4C). The most striking and important observation we made is a synergistic induction of $S C X$ expression at $24 \mathrm{~h}$. Whereas $S C X$ levels on PS-1018 were 3.5 fold higher compared to a regular flat surface, TGF- $\beta 2$ stimulation alone resulted in a 14.5 fold increase in SCX levels compared to flat. Of interest here is that the combined exposure of MSCs to PS-1018 and TGF- $\beta 2$ induced SCX 39.9 fold. This synergy was already detected after $8 \mathrm{~h}$, although at lower levels, and was observed during the whole seven days culture period. It is interesting to note that $S C X$ expression declines over time, which could be related to the transient upregulation of the early response genes and TGF- $\beta R$-II.

The synergistic response to TGF- $\beta 2$ on surface PS-1018 was not unique to MSCs. We induced a similar biological response in human dermal fibroblasts and C3H10T1/2 cells, a mouse mesenchymal-like cell line that is frequently utilized in differentiation studies (Fig. 4D). These findings demonstrate that the synergy between TGF- $\beta$ signaling and surface topography is reproducible in multiple TGF- $\beta 2$-response cell 
A

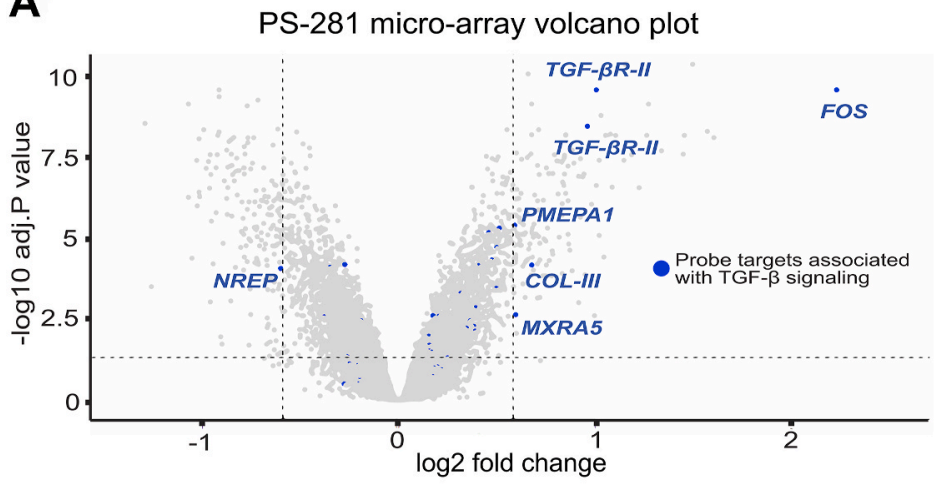

C SCX levels on PS-1018

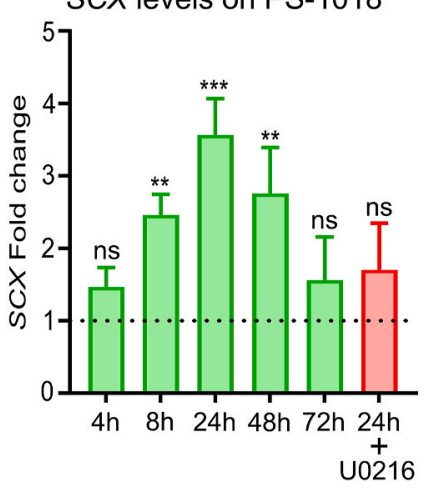

B

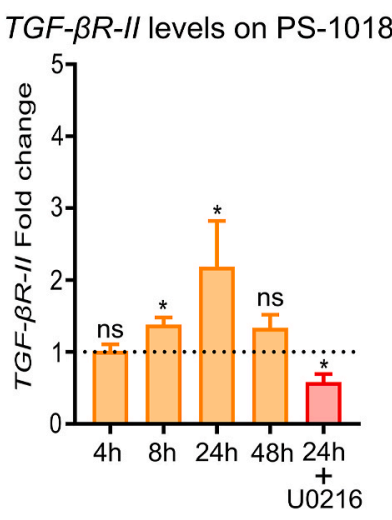

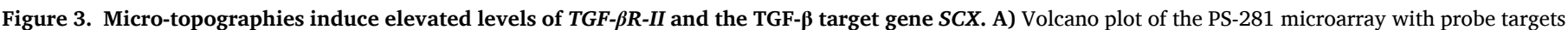

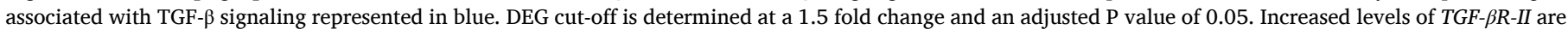

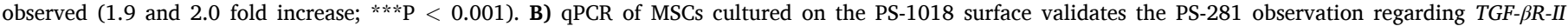

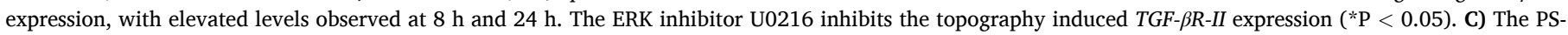

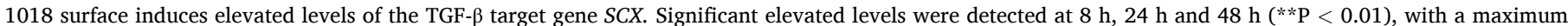

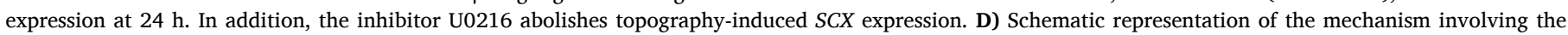

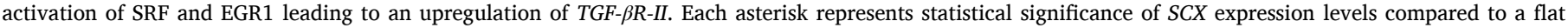
control condition. Barplots represent the mean with error bars representing SEM.

lines. Besides SCX, we also found a similar effect for other TGF- $\beta$ responsive genes. Expression of $\alpha$-SMA, a differentiation marker of smooth muscle cells and myofibroblasts [62], and the chondrogenic transcription factor SOX9 [63] can be induced by TGF- $\beta 2$, and display a synergistic effect when combined with micro-topographies (Fig. 4E and F). These observations demonstrate that micro-topographies sensitize cells for TGF- $\beta$ signaling.

\subsection{Rho/ROCK/SRF signaling is required for topography-induced TGF- $\beta$ sensitization}

We next set out to investigate the signaling events that occur between surface topography-induced actin-mediated signaling and transcriptional activation of TGF- $\beta$ target genes, by investigating the synergistic effect in the presence of several small-molecule inhibitors of signal transduction (Fig. 5). We confirmed the synergy in the presence of DMSO, the diluent of the inhibitors used in the rest of the study (Fig. 6A), and validated that $S C X$ gene expression is indeed dependent on TGF- $\beta$ receptor activation, using its inhibitor SB431542 [64] (Fig. 6B). Interestingly, this compound abolished SCX expression in MSCs on PS-1018 alone, which indicates that even without the addition of TGF- $\beta 2$, TGF- $\beta /$ SMAD signaling is occurring. This may hint at auto- or paracrine signaling elicited by the MSCs, or TGF- $\beta$ originating from the serum media.

Next, we studied the effect of the Rho-associated protein kinase (ROCK) inhibitor Y27632, because Rho proteins influence numerous biological responses, including cell shape and actin cytoskeletal rearrangement [65] and are important for driving cell behavior of cells grown on physical cues. Y27632 did not affect the induction of SCX by TGF- $\beta 2$ on flat control surfaces but did abolish the synergistic effect on the PS-1018 surface (Fig. 6C). Very similar results were obtained with CCG-203971, a compound which inhibits SRF/Myocardin Related Transcription Factor A (MRTF) gene transcription [66] (Fig. 6D) and blebbistatin (Fig. 6E), an inhibitor of non-muscle myosin-II [67] which prevents actin-myosin interaction resulting in subsequent disruption of actin dynamics [68]. Of interest, utilizing the MEK inhibitor U0216 did lower the level of SCX but did not abolish the synergistic effect (Fig. 6F), which indicates that the topography-induced mechanotransduction is not guided through MAPK signaling. These observations demonstrate that actin dynamics and the Rho/ROCK/SRF signaling pathway are necessary for micro-topographies to enhance the expression of $S C X$.

\section{6. $P K C$ activators mimic topography-induced mechanotransduction}

Small molecules that inhibit actin-related signaling were able to block topographic induction of TGF- $\beta 2$ signaling, so vice versa, it may be possible to mimic topographic mechanotransduction with small molecules that mimic actin-related signaling. To find these molecules, we searched the Connectivity Map, a compendium of more than one million gene expression profiles induced by small molecules and genetic perturbations, which is used for determining similarities in gene expression profiles between these perturbations [69]. We previously described that topography-induced TGF- $\beta 2$ signaling coincides with high levels of F-actin and concomitant SRF signaling after $1 \mathrm{~h}$, but reduced F-actin and 
A

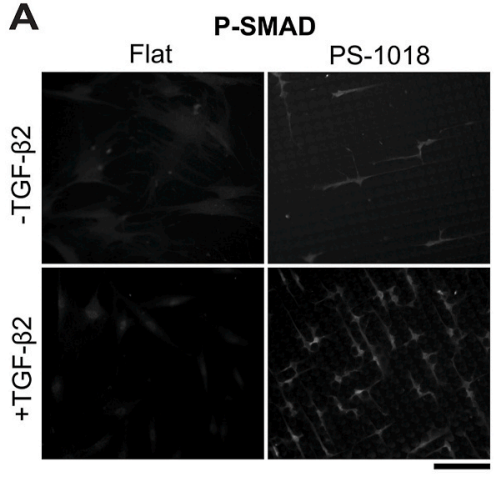

B

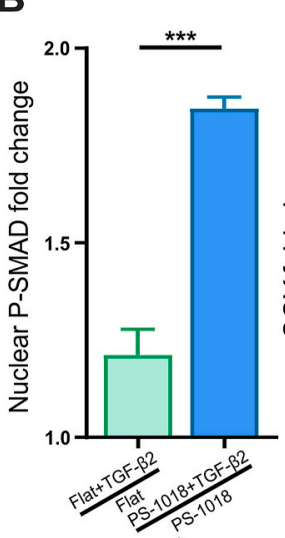

C

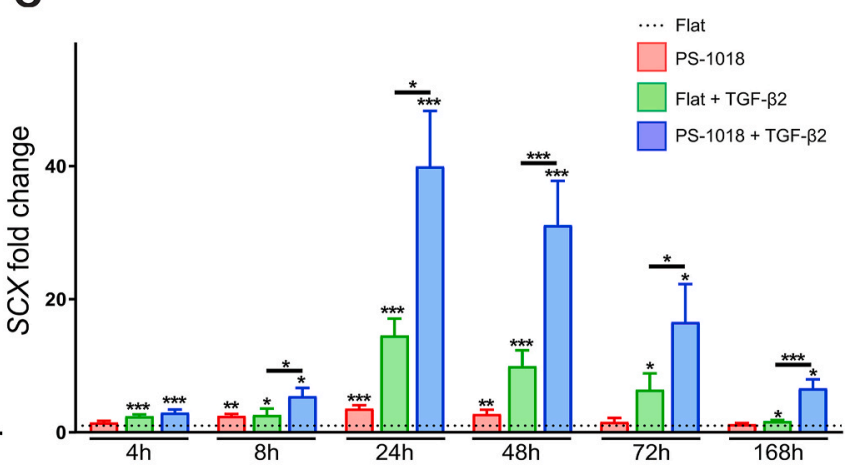

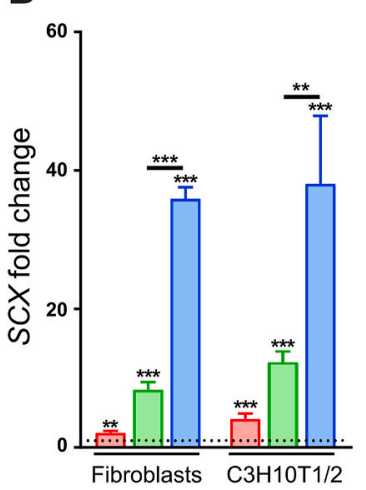

E

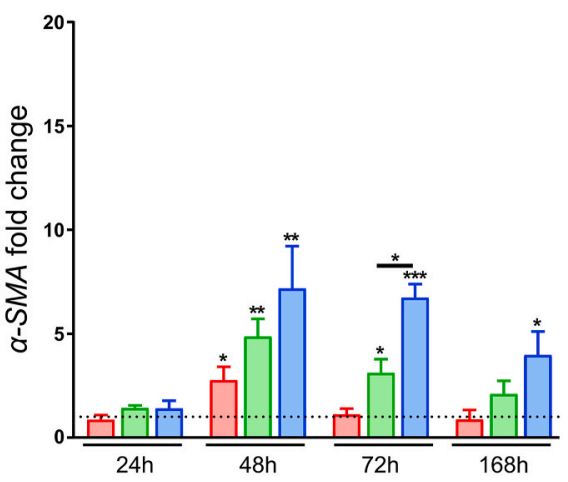

$\mathbf{F}$

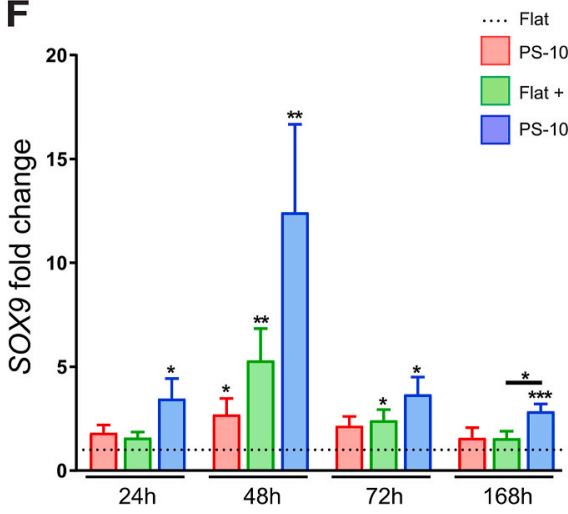

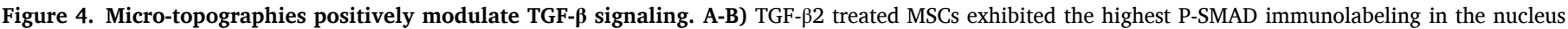

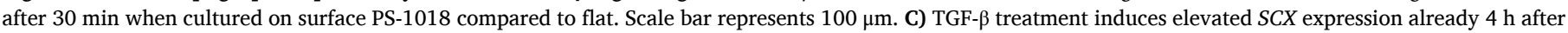

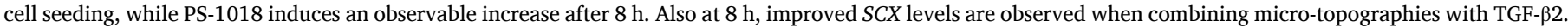

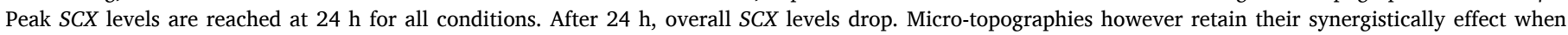

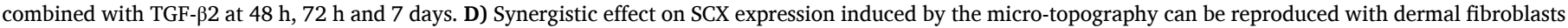

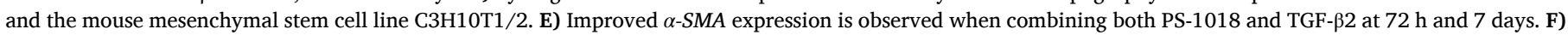

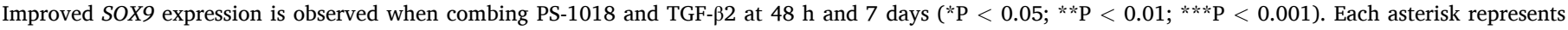

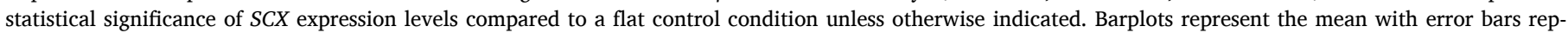
resenting SEM.

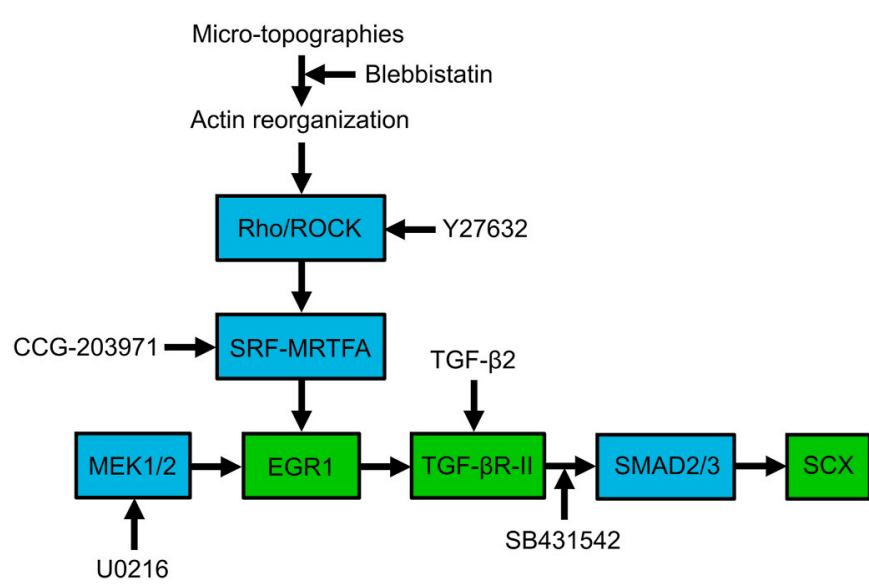

Figure 5. Mechanistic pathway scheme of how micro-topographies might induce a synergistic effect in the expression of TGF- $\beta$ target genes. Included are the inhibitors used to block the activation of these pathways.

lower expression of genes related to Rho/ROCK/SRF signaling after 24 h. We reasoned that topography mimicking small molecules should, therefore, recapitulate the actin dynamics observed on topographies. The Connectivity Map only contains gene expression data from later time points, and we therefore retrieved small molecules using the gene expression fingerprint of cells in which $\beta$-actin, $S R F$, and FOS genes were knocked down as bait for the search (Fig. 7A-C), because this best reflects the lower Rho/ROCK/SRF signaling axis after $24 \mathrm{~h}$. Of interest, perturbagen class "Protein Kinase C (PKC) activators" was present in the lists of $\beta$-actin (ACTB), SRF, and FOS and thus resembles gene signatures associated with these knockdowns. Furthermore, in the list of PKC activators, "MEK inhibitors" were present with a negative score, which could indicate a positive involvement for EGR1 (Fig. 7D). Also for tubulin, of which we see a decrease of multiple isoforms in the microarray data, we see an association with PKC activators (Supplementary Fig. 7), suggesting that treatment of cells with PKC activators leads to similar gene expression profiles as when ACTB, SRF, and FOS are knocked-down.

PKC activators can induce actin reorganization [70], which eventually leads to a decrease in actin stress fibers [71]. Furthermore, they can activate FOS [72] and EGR1 [73]. This makes this perturbagen class an interesting candidate for molecules that can mimic topography-induced TGF- $\beta$ sensitization (Fig. 7E). We want to mention that in the $\beta$-actin knockdown gene fingerprint list, we found gene signature resemblances with other perturbagens such as cytochalasin-B, a microtubule inhibitor, and cytochalasin-D, an actin polymerization inhibitor (Supplementary Fig. 8). However, as shown with the actin polymerization inhibitor blebbistatin, this compound fails to recapitulate the synergistic effect with TGF- $\beta 2$, since unlike PKC activators, no activation of early response genes is achieved. Also of interest is that an EGR1 knockdown corresponds strongly with the gene signature of a TGF- $\beta R-I I$ knockdown, further emphasizing the relationship between these genes 

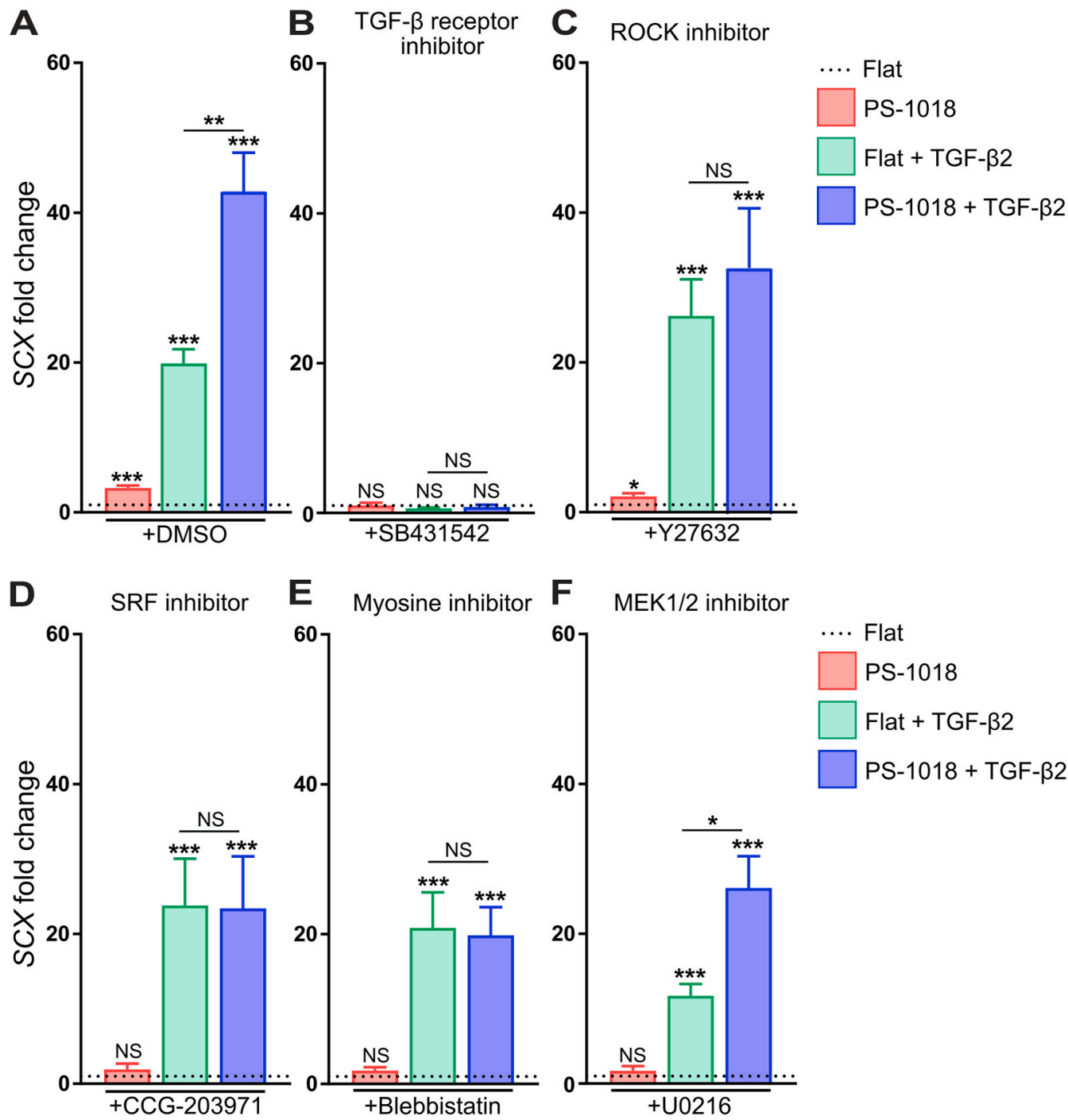

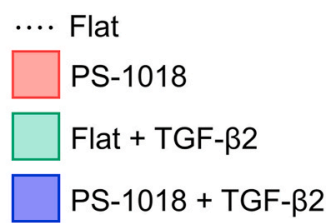

Figure 6. Pathway inhibitors reveal that micro-topographical induced $S C X$ expression requires Rho/ROCK/ SRF signaling. A) DMSO does not affect $S C X$ levels in each condition. B) Inhibitors against the TGF- $\beta$ receptor abolish SCX levels on all conditions including PS-1018, emphasizing the involvement of TGF- $\beta$ signaling for micro-topographical induction of SCX. C-E) The Rho/ROCK/SRF inhibitors Y27632, CCG-209371, and blebbistatin abolishes the topography-induced effect on SCX expression. F) The MAPK/MEK inhibitor U0216 reduces overall SCX expression, yet does not reduce the synergistic effect on SCX expression (ns $=$ non-significant; $* \mathrm{P}<0.05 ; * * * \mathrm{P}<$ 0.001). Each asterisk represents statistical significance of $S C X$ expression levels compared to a flat control condition unless otherwise indicated. Barplots represent the mean with error bars representing SEM.
(Supplementary Fig. 9).

From the PKC activator component list (Supplementary Fig. 10), ingenol and prostratin were added to MSCs with and without TGF- $\beta 2$, and SCX levels were measured after $24 \mathrm{~h}$. Without TGF- $\beta 2$, ingenol and prostratin induced similar $S C X$ levels as the PS-1018 surface (Fig. 7F). In the presence of TGF- $\beta 2$, prostratin induced a 36.2 fold $S C X$ expression compared to a regular flat surface without TGF- $\beta 2$. Ingenol-3 induced a similar response, with slightly higher SCX levels (39.1 fold change) than prostratin. No significant differences between the topography and PKC activators were observed when adding TGF- $\beta 2$. These findings demonstrate that PKC activators strikingly mimic the effect of the microtopography in inducing $S C X$ levels.

In previous work, we found that tenocytes rapidly lose their phenotypic characteristics in cell culture [42]. This is characterized by the transformation of a spindle-shape morphology towards a spread-out morphology, coinciding with the formation of F-actin stress fibers. Furthermore, it is known that already during the initial in vitro culturing, tenogenic marker expression decreases, as shown for $S C X$ [74]. We were therefore interested in investigating if PKC activators could improve phenotypic characteristics in tenocyte culture. Therefore, we treated passage one tenocytes with- and without the PKC activators and TGF- $\beta 2$ and found more profound spindle-shaped characteristics in confluent conditions when cells were treated with ingenol, both without and with TGF- $\beta 2$ (Fig. 8A). To further investigate their morphological characteristics, we fixed cells $72 \mathrm{~h}$ after adding the compounds and stained for
F-actin, and SCX. Ingenol caused an apparent reduction in F-actin stress fibers and a decrease in F-actin intensity levels (Fig. 8B). Of interest is that TGF- $\beta 2$ induces a more spread out morphology, which coincided with higher F-actin levels. This observation was also abolished by ingenol. We found that TGF- $\beta 2$ was able to increase SCX levels, which could be further amplified by the ingenol treatment (Fig. 8C). These novel findings demonstrate that PKC activators replace the synergistic effects of the micro-topography both in the context of TGF- $\beta$ induced MSC differentiation and phenotypic maintenance of tenocytes.

\section{Discussion}

We present evidence that TGF- $\beta$ signaling is positively modulated through mechano-induced topographical cues. This work emphasizes the importance of recapitulating the crosstalk typically seen in vivo between mechanical and soluble cues in an in vitro culture setting. In addition, the results of this work put other research from the tissueengineering field in a new perspective. BMP-2 is a growth factor that improves bone formation in a clinical setting, but only at unphysiologically high levels of the protein [75]. We hypothesize that BMP-2 is presented in the wrong mechanical context, and mechanical fine-tuning can lead towards greater efficacy. Research combining BMP-2 with mechanical loading indeed seems to indicate this [76]. Similarly, VEGF promotes angiogenesis, yet it also leads to vascular disruption [77]. Here it is plausible that the underlying mechanisms will 
A

\begin{tabular}{|c|c|c|c|c|}
\hline \multicolumn{3}{|c|}{ ACTB perturbagen class score } & \multicolumn{2}{|c|}{ SRF perturbagen class score } \\
\hline Score & \multicolumn{2}{|c|}{ Name } & Score & Name \\
\hline 96.44 & \multicolumn{2}{|c|}{$\mathrm{BCL}$ inhibitor } & 97.90 & Tubulin inhibitor \\
\hline 96.09 & \multicolumn{2}{|c|}{ HIF activator } & 95.69 & PKC activator \\
\hline 95.04 & \multicolumn{2}{|c|}{ Ribonucleotide reductase inhibitor } & 93.87 & Wnt family LOF \\
\hline 94.94 & \multicolumn{2}{|c|}{ PKC activator } & 93.49 & Kruppel like transcription \\
\hline \multicolumn{5}{|l|}{ D } \\
\hline \multicolumn{5}{|c|}{ PKC perturbagen class score } \\
\hline \multirow[t]{11}{*}{ A B C } & Score & Name & \multirow{3}{*}{\multicolumn{2}{|c|}{\begin{tabular}{|l|}
$\mathbf{A}=$ Ingenol \\
$\mathbf{B}=$ Phorbol-12-myristate-13-acetate \\
$\mathbf{C}=$ Prostratin
\end{tabular}}} \\
\hline & 99.98 & PKC activator & & \\
\hline & 99.9 & NFKB Activation GOF & & \\
\hline & 99.53 & HIF activator & & \\
\hline & 99.33 & IKK inhibitor & & \\
\hline & 99.25 & MTOR inhibitor & & \\
\hline & -1.2 & P38 MAPK inhibitor & & \\
\hline & -5.53 & GPCR Subset GOF & & \\
\hline & -10.32 & Non Homologous End Join & hing LOF & \\
\hline & -75.7 & Integrin subunits beta LOF & & \\
\hline & -98.08 & MEK inhibitor & & \\
\hline
\end{tabular}

F

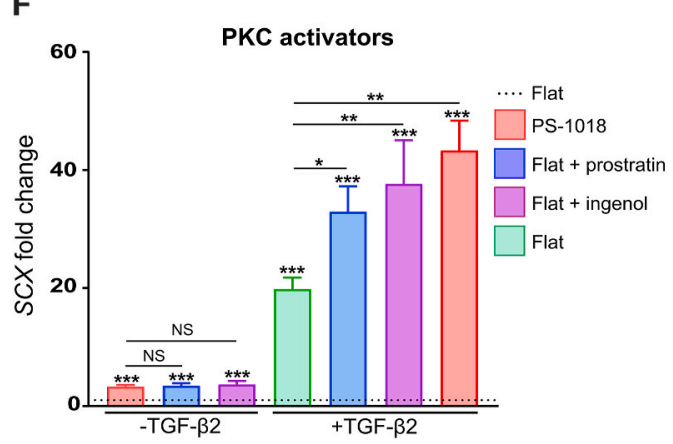

C

$\begin{array}{cl}\text { FOS perturbagen class score } \\ \text { Score } & \text { Name } \\ 94.61 & \text { NFKB activation GOF } \\ 92.74 & \text { PKA inhibitor } \\ 88.94 & \text { Glycogen synthase kinase inhibitor } \\ 88.48 & \text { PKC activator }\end{array}$

E

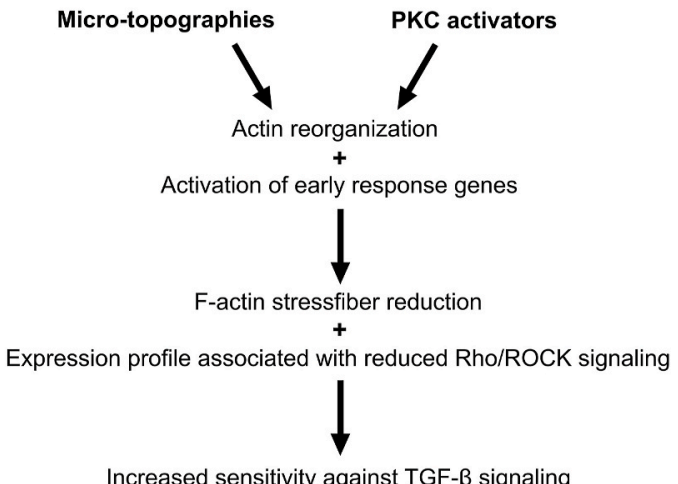

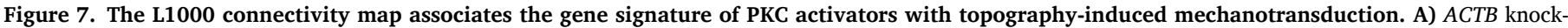

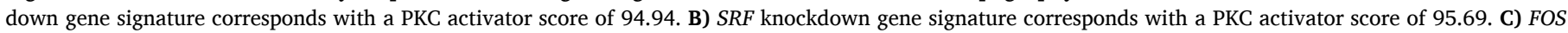

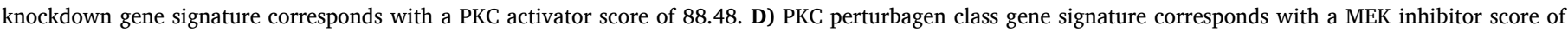

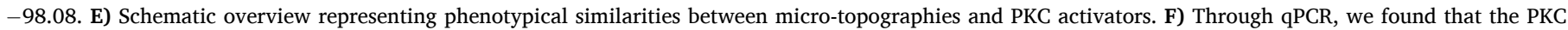

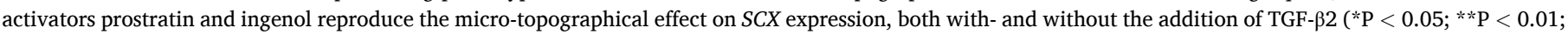

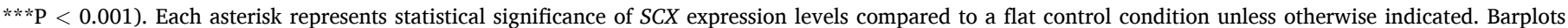
represent the mean with error bars representing SEM.

be better controlled by implementing alternative stimulation as well. It is therefore interesting to reconsider growth factor-mediated cell differentiation and cell growth in the context of biomechanical conditions.

In an in vitro context, other studies involving geometrical-induced modulation of tenogenic gene expression do not consider the potential synergistic effects of growth factor signaling in their experimental setup [42,78-82]. An exception is a study documenting improved SCX expression in a dermal fibroblast culture on micro-grooves combined with TGF- $\beta 1$ [83]. Besides micro-topographies, other physical cues such as scaffolds enhance tenogenic characteristics of MSCs and progenitor cells [84,85], making this also an interesting material design for exploring if they modulate TGF- $\beta$ signaling. In this context, matrix stiffness can influence $S C X$ expression [86], another physical parameter known for modulating TGF- $\beta$ signaling [87-89]. Our setup involving micro-topographies and TGF- $\beta 2$ allowed for a strong induction in SCX expression compared to solely changing the material parameters, or the addition of TGF- $\beta$ [26]. Additional research will however be required to determine if this combined setup induces true tenogenesis in MSCs by profiling their gene expression and comparing this with that of tenocytes. Since the biomechanical stimulation that the micro-topographies exert on SCX expression and other TGF- $\beta$ target genes is transient, it might in the future be interesting to introduce TGF- $\beta$ in a culture system with a combination of both micro-topographies and mechanical stretching $[90,91]$, of which the latter improves tenogenesis in MSCs as well $[92,93]$. These examples highlight the potential of future research involving biomaterials that investigate interactions with TGF- $\beta$ signaling in a tissue-engineering context.

In this study, we found mechanobiological signaling similarities with other experimental setups. For example, increased levels of EGR1 during the cell adaptation phase are also found early upon cell stretching together with increased levels of FOS [32]. EGR1 plays a crucial role in tenocyte mechanical signaling and can influence TGF- $\beta$ R-II [52], SCX, and other tenogenic markers [49-51]. It is therefore not surprising that mechanical stimulation through stretching is studied extensively for inducing MSC differentiation [92,94], and tenogenic matrix deposition [95]. Furthermore, a clear link exists between mechanical forces and TGF- $\beta$ /SMAD activation in numerous cell types $[93,96,97]$. SRF activity plays a central role in mediating actin dynamics [14,98], which is clearly altered and dynamically modulated by physical cues in this study. A plausible scenario is that SRF binds to serum response elements (SRE) in its promotor and those of FOS [47] and EGR1 [99], triggering the biological events we observe. This concept is further emphasized through the use of PKC activators, known to induce SRE activation [72], and thereby mimicking the effect of the topography. Although physical cues can regulate Rho/ROCK signaling [19], evidence points towards $\mathrm{SRF}$ as a subsequent and essential mediator in the observed biomechanical signaling events $[22,24,25]$. Also, experimental readouts that involve mechanical stretching can be blocked by inhibiting the Rho/ROCK/SRF pathway $[100,101]$. Related to this, the concept that SRF is involved in TGF- $\beta$ signal transduction is not novel. Evidence exists that 
A
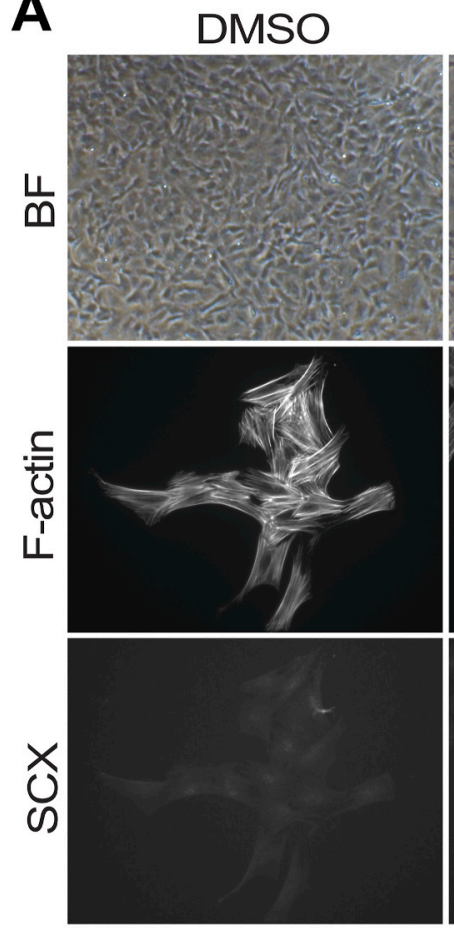

B

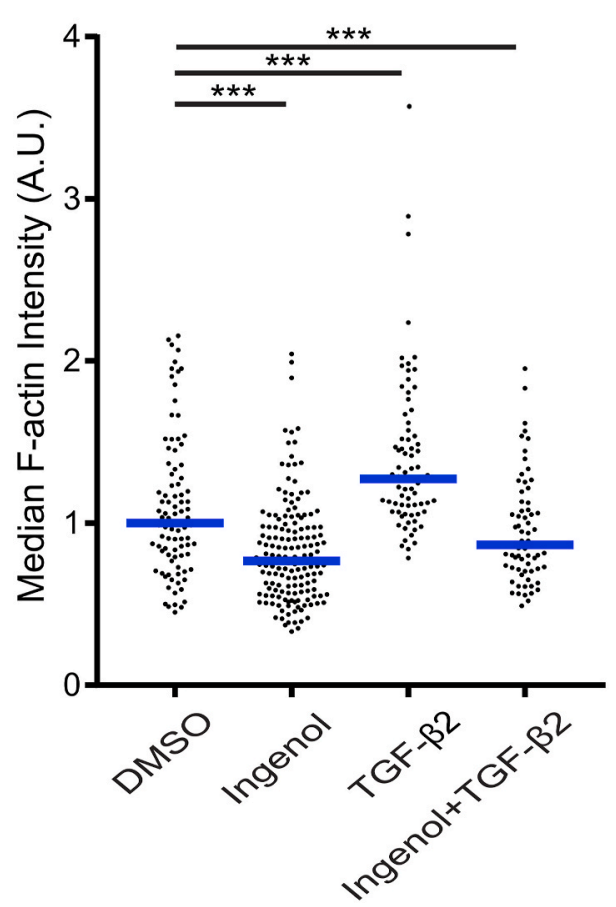

Ingenol
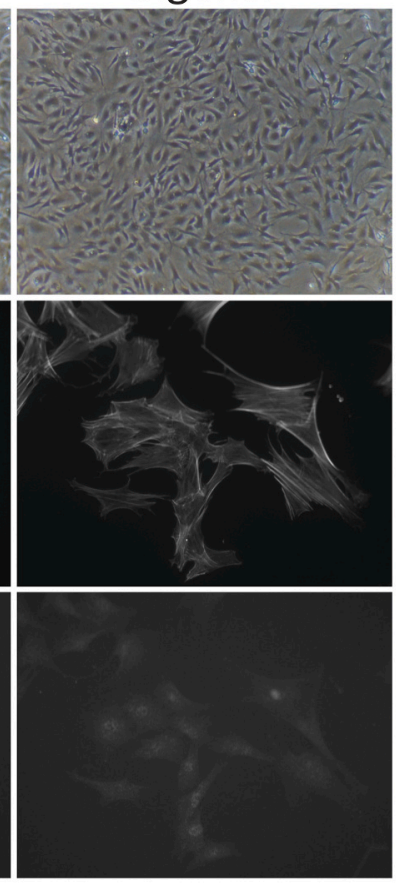

TGF-B2
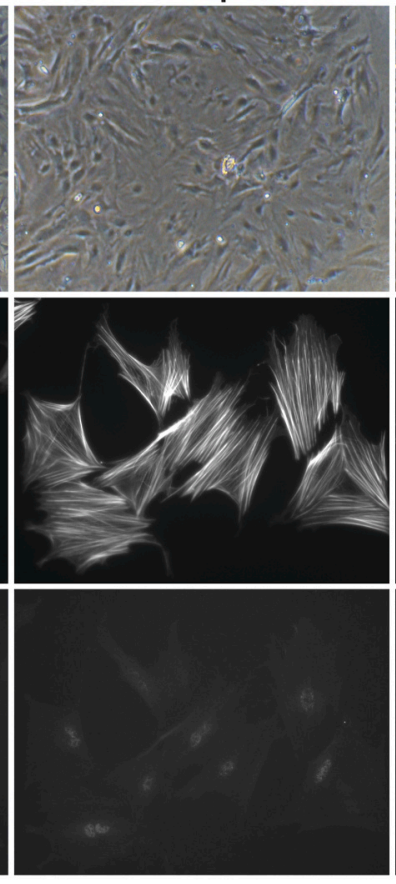

Ingenol+TGF-ß2
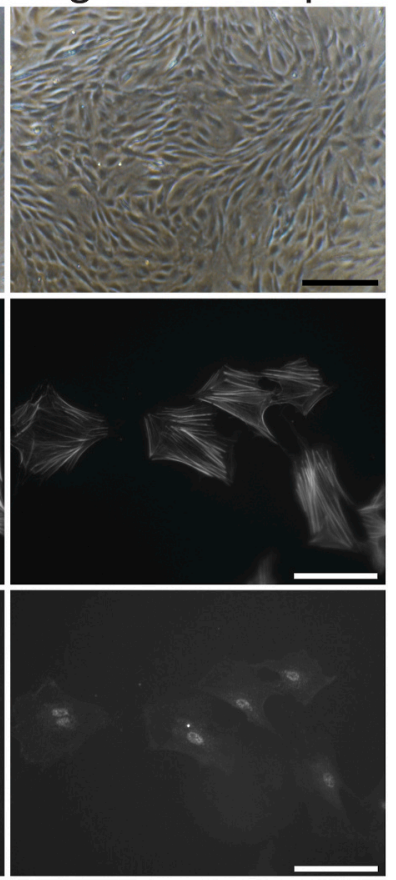

\section{C}

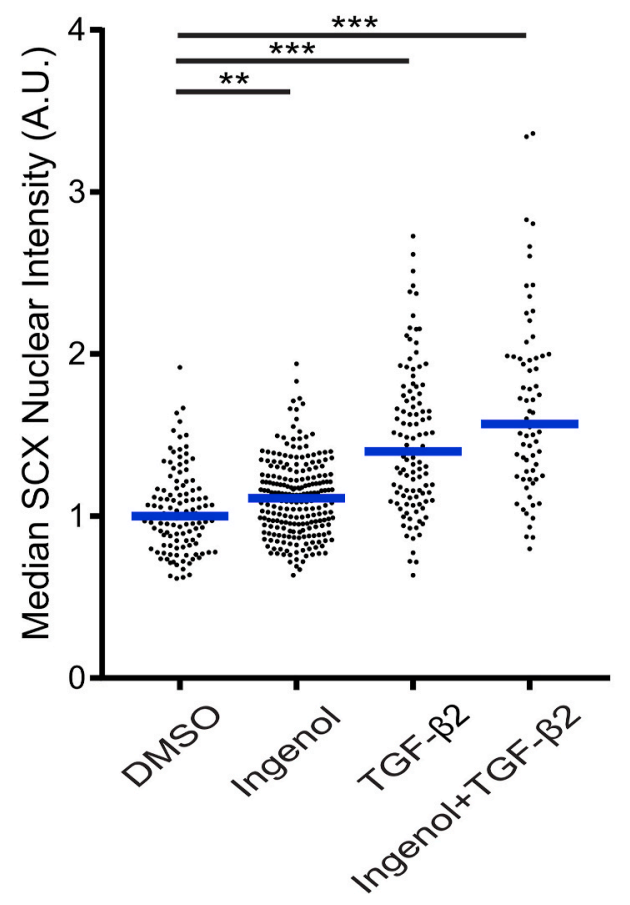

Figure 8. PKC activators reduce F-actin and elevate SCX in tenocytes. A) Ingenol-3 induces elongated cell characteristics in confluent conditions. Furthermore, reduced F-actin levels in tenocytes both with- and without a TGF- $\beta 2$ treatment are observed when treated with ingenol. Similar as shown with MSCs, SCX levels increase in tenocytes with PKC activator treatment. Scale bar represent $100 \mu \mathrm{m}$. B) F-actin immunolabeling quantification reveals significant lower levels when tenocytes are treated with ingenol, both with- and without TGF- $\beta 2$. C) SCX immunolabeling quantification reveals significant increased levels when cells are treated with ingenol and TGF- $\beta 2$, with a most optimal effect when combining both perturbations ( $* * * \mathrm{P}<0.001$ ). Dotplots represent either F-actin intensity levels of individual cells, or SCX intensity levels of individual nuclei. Blue line indicates median.

force-induced activation of $\alpha$-SMA and subsequent fibrosis is blocked by inhibiting the Rho/ROCK pathway and subsequent SRF activity [17, 102].

This research provides novel insights into how physical cues transmit mechanobiological signaling. Especially the dynamical nature of the signaling cascades elicited by the micro-topographies is interesting. Parts of the mechanisms behind the phenomena we observe are however still unknown. For example, we do not rule out that FOS plays a role in TGF- $\beta$ sensitization due to a binding affinity against SMAD2/3 [53]. Also, despite the apparent requirement of SRF for inducing TGF- $\beta$ 
sensitivity, other transcription factors might play a role in activating SRE's of EGR1 and FOS in conjunction with SRF [103]. More insights will need to be gained by investigating how much pathway overlap there is between physical cues, PKC activation, and mechanical stretching. The observation that PKC activators mimic topography-induced biomechanical stimulation is a fascinating concept since it extends the translational perspectives of our experiments. Small molecules inducing the same synergistic effect as micro-topographies could be introduced into a clinical context where mechanical loading events typically support tissue repair. For tendon tissue-engineering, this implies the potential to utilize PKC activators for stimulating a growth factor-mediated healing response, which might improve current clinical treatments [104].

\section{Conclusion}

We demonstrate that micro-topographies influence TGF- $\beta$ signaling in MSCs, leading to increased expression of the differentiation markers SCX, SOX9, and $\alpha$-SMA. We connect the origin of this mechanobiological signaling with actin remodeling elicited by physical cues, which coincides with subsequent activation of early response genes associated with an upregulation of TGF- $\beta$ R-II. Through extensive pathway analysis, we identify small molecule compounds that mimic the effect of the micro-topography. The results of this study can lead to improved protocols for the differentiation of MSCs or phenotypic maintenance of primary cells involving TGF- $\beta$ signaling. Furthermore, the identification of small molecules that mimic mechanobiological stimulation might be applied in a clinical setting for replacing mechanical stimulation in conjunction with soluble cues.

\section{Materials and methods}

\subsection{Surface fabrication}

A detailed description of the surface fabrication procedures is found elsewhere [105]. In short, the inverse pattern of the topographies was etched into a silicon wafer by directional reactive ion etching (DRIE). To facilitate demoulding procedures, the wafer was coated with a layer of Trichloro(1H,1H,2H,2H-perfluorooctyl)silane (FOTS, Sigma-Aldrich). Polydimethylsiloxane (PDMS; Down Corning) was cured on the silicon wafer to generate a positive mould and was subsequently used as a template to create a second negative mould in Ormostamp polymer (micro resist technology Gmbh), which serves as the mould for hot embossing the polystyrene (PS) films (Goodfellow). The hot embossing procedure was carried out at $140{ }^{\circ} \mathrm{C}$ for $5 \mathrm{~min}$, and a pressure of $10 \mathrm{Bar}$, with a demoulding temperature of $90{ }^{\circ} \mathrm{C}$. Before cell culture, the PS topographies were treated with oxygen plasma to improve cell adhesion for $30 \mathrm{~s}$ at $0.8 \mathrm{mbar}, 50 \mathrm{sccm} \mathrm{O}_{2}$, and $100 \mathrm{~W}$. Quality of the fabricated imprints was assessed using a Keyence VK-H1XM-131 profilometer.

\subsection{Cell culture}

Adipose-derived human mesenchymal stem cells (AD-hMSCs) and dermal fibroblasts (DF) used in this study were purchased from Lonza. AD-hMSCs and DF were isolated from a 42-year-old, and 27-year-old female respectively. C3H10T1/2 cells were purchased at ATCC. All methods were performed in accordance with the relevant ethical guidelines and regulations of the University of Maastricht. Basic medium for AD-hMSCs and DF consists of MEM Alpha GlutaMAX, no nucleosides (Gibco). For the culture of C3H10T1/2 cells, DMEM low glucose (Merck) was used as basic media. Basic media was supplemented with $10 \% \mathrm{v} / \mathrm{v}$ fetal bovine serum (FBS), $0.2 \mathrm{mM}$ ascorbic-acid-2-phosphate (ASAP), and $10 \mathrm{U} / \mathrm{mL}$ Penicillin/Streptomycin. Cells were grown at $37{ }^{\circ} \mathrm{C}$ in a humid atmosphere at $5 \% \mathrm{CO}_{2}$. For experimental purposes, cells at passage 3-4 were seeded at a density of 5000-10000 cells $/ \mathrm{cm}^{2}$ on flat and the topographical surface. Human TGF- $\beta 2$ (Peprotech), and mouse TGF- $\beta 2$ (R\&D Systems) were included in the media during cell seeding at a final concentration of $20 \mathrm{ng} / \mathrm{ml}$. Pathway inhibitors blebbistatin, Y27632, CCG-203971, U2016, and SB431542 were purchased from Sigma-Aldrich and included in the media at a final concentration of 10 $\mu \mathrm{M}$. For inhibitor studies, inhibitors were added to the cell media $1 \mathrm{~h}$ prior and during cell seeding. PKC activators Ingenol, and Prostratin were purchased from Sigma-Aldrich, and added to the medium at a final concentration of $10 \mu \mathrm{M}$ during cell seeding or media replacement.

\subsection{Microarray study and pathways analysis}

Bone marrow-derived human MSCs were seeded on topography PS281 for $24 \mathrm{~h}$ in basic medium at a density of 15,000 cells/cm2 in 24 well plates in three replicas. Total RNA was isolated using the Nucleospin RNA isolation kit (Macherey-Nagel). Then, from 100 ng of RNA, cRNA was synthesized using the Illumina TotalPrep RNA amplification kit. Both RNA and cRNA quality was verified on a Bioanalyzer 2100 (Agilent). Microarrays were performed using Illumina HT-12 v4 expression Beadchips. 750 ng of cRNA was hybridized on the array overnight, after which the array was washed and blocked. Then, through the addition of streptavidin Cy-3, a fluorescent signal was developed. Arrays were scanned on an Illumina Beadarray reader, after which raw intensity values were background corrected in BeadStudio (Illumina). Further data processing and statistical testing were performed using the online portal arrayanalysis.org. The probe-level raw intensity values were quantile normalized and transformed using variance stabilization (VSN). A detection threshold of 0.01 was used for reducing the number of false positives. A linear modelling approach with empirical Bayesian methods, as implemented in Limma package, was applied for differential expression analysis of the resulting probe-level expression values.

To construct a gene network of the DEGs, we applied an online STRING analysis (https://string-db.org/). Only DEG with a fold change higher than 1.5 and an adjusted p-value lower than 0.05 were included in the list.

For identifying small molecules that mimic topography-induced pathways, we searched for relevant genes affected by the microtopography in the connectivity map (https://clue.io/).

\subsection{Phospho proteomics study}

\subsubsection{In-liquid digestion}

A total of $60 \mu \mathrm{g}$ protein in $50 \mu \mathrm{l} 50 \mathrm{mM}$ ammonium bicarbonate (ABC) with $5 \mathrm{M}$ urea was used. $5 \mu \mathrm{L}$ of dithiothreitol (DTT) (20 mM final) was added and incubated at room temperature for $45 \mathrm{~min}$. The proteins were alkylated by adding $6 \mu \mathrm{L}$ of IAA solution ( $40 \mathrm{mM}$ final). The reaction was taken place at room temperature for $45 \mathrm{~min}$ in the darkness. The alkylation was stopped by adding $10 \mu \mathrm{L}$ of DTT solution (to consume any unreacted IAA) and incubated at room temperature for $45 \mathrm{~min}$. For the protease digestion, $2 \mu \mathrm{g}$ trypsin/lysC was added to the protein and incubated at $37^{\circ} \mathrm{C}$ for $2 \mathrm{~h}$. $200 \mu \mathrm{l}$ of $50 \mathrm{mM} \mathrm{ABC}$ was added to dilute the urea concentration and further incubate at $37^{\circ} \mathrm{C}$ for $18 \mathrm{~h}$. The digestion mix was centrifuge at $2 \times 10^{3} \mathrm{~g}$ for $5 \mathrm{~min}$ and the supernatant collected.

Phospho-peptides were enriched by using TiO2 spin columns according the manufacturers protocol (Thermo Scientific). Samples were subsequently labeled with TMT isobaric mass tagging labelling reagent (10-plex; Thermo Scientific) according to the manufacturer's protocol. In short, $60 \mu \mathrm{g}$ of protein for each sample was used. The TMT labelling reagents were dissolved in $41 \mu \mathrm{l}$ acetonitrile per vial. The reduced and alkylated samples and control were added to the TMT reagent vials. The reaction was incubated for $1 \mathrm{~h}$ at room temperature and quenched for $15 \mathrm{~min}$ by adding $8 \mu \mathrm{l}$ of $5 \%$ hydroxylamine. Equal amounts of the samples and control were combined in a new vial and analyzed by liquid chromatography-tandem mass spectrometry (LC-MS/MS).

\subsubsection{Protein identification using LC-MS/MS}

A nanoflow HPLC instrument (Dionex ultimate 3000) was coupled 
on-line to a Q Exactive (Thermo Scientific) with a nano-electrospray Flex ion source (Proxeon). The final concentration of the TMT labeled digest/ peptide mixture was $0.33 \mu \mathrm{g} / \mu \mathrm{l}$ and $5 \mu \mathrm{l}$ of this mixture was loaded onto a C18-reversed phase column (Thermo Scientific, Acclaim PepMap C18 column, $75-\mu \mathrm{m}$ inner diameter $\mathrm{x} 15 \mathrm{~cm}, 2-\mu \mathrm{m}$ particle size). The peptides were separated with a 90 min linear gradient of $4-68 \%$ buffer B $(80 \%$ acetonitrile and $0.08 \%$ formic acid) at a flow rate of $300 \mathrm{~nL} / \mathrm{min}$.

MS data was acquired using a data-dependent top-10 method, dynamically choosing the most abundant precursor ions from the survey scan $(280-1400 \mathrm{~m} / \mathrm{z})$ in positive mode. Survey scans were acquired at a resolution of $70 \times 10^{3}$ and a maximum injection time of $120 \mathrm{~ms}$. Dynamic exclusion duration was $30 \mathrm{~s}$. Isolation of precursors was performed with a $1.8 \mathrm{~m} / \mathrm{z}$ window and a maximum injection time of $200 \mathrm{~ms}$. Resolution for HCD spectra was set to 30,000 and the Normalized Collision Energy was $32 \mathrm{eV}$. The under-fill ratio was defined as $1.0 \%$. The instrument was run with peptide recognition mode enabled, but exclusion of singly charged and charge states of more than five.

\subsubsection{Database search}

The MS data were searched using Proteome Discoverer 2.2 Sequest HT search engine (Thermo Scientific), against the UniProt human database. The false discovery rate (FDR) was set to 0.01 for proteins and peptides, which had to have a minimum length of six amino acids. The precursor mass tolerance was set at 10 parts per million (ppm) and the fragment tolerance at $0.02 \mathrm{Da}$. One miss-cleavage was tolerated, Phosphorylation of serienes, tyrosines and threonines as well as oxidation of methionine were set as a dynamic modification. Carbamidomethylation of cysteines, Tandem mass tag (TMT) reagent adducts $(+229.162932$ Da) on lysine and peptide amino termini were set as fixed modifications.

\subsection{Immunocytochemistry}

After cell culture, the cells were washed with phosphate buffered saline (PBS; Merck) and fixed with $4 \%(\mathrm{w} / \mathrm{v})$ paraformaldehyde (SigmaAldrich) for $5 \mathrm{~min}$ at $37{ }^{\circ} \mathrm{C}$. After a washing step, cells were permeabilized with $0.01 \%(\mathrm{v} / \mathrm{v})$ Triton X-100 (Acros Organics) and blocked with goat serum (1:100; Sigma-Aldrich) in PBT (PBS $+0.02 \%$ Triton-X$100,0.5 \% \mathrm{BSA}$ ) for $1 \mathrm{~h}$. Afterwards, cells were incubated with the primary antibody in PBT for $1 \mathrm{~h}$. After a washing step, cells were incubated with a secondary antibody targeting the primary antibody protein of interest and conjugated to an Alexa Fluor (1:500; ThermoFisher) in PBT. After washing, the nucleus was counterstained with Hoechst 33258 (1:1000; Sigma-Aldrich) for $10 \mathrm{~min}$. After a subsequent washing step, surfaces were mounted on glass cover slides with mounting media (Dako). All washing steps were performed in triplicate with PBT. Primary antibodies used in this study are: anti-SCX antibody (1:200; Abcam; ab58655), anti-EGR1 antibody (1:200; ThermoFisher; T.126.1), anti- Phospho-Smad2/3 (1:200; Cell Signaling Technologies; 8828S), and anti-SRF antibody (1:200; Santa Cruz; sc-335).

\subsection{Image analysis}

Fixed samples were inverted and fluorescent images were acquired through the glass coverslip using a fully automated Nikon Eclipse Ti-U microscope in combination with an Andor Zyla 5.5 4 MP camera. Fluorescent images were analyzed through CellProfiler 3.1.8 [106] applying custom-made pipelines. All images were cropped in order to remove out-of-focus objects. Objects touching the border of the subsequent images were filtered out of the dataset. After illumination corrections, morphology of the nucleus was captured by the Otsu adaptive thresholding method applied on the Hoechst 33258 image channel. Subsequently, cell morphology was determined by applying propagation and Otsu adaptive thresholding on the Phalloidin image channel. Missegmentation artifacts were removed by applying an arbitrary threshold on nuclei and cell size. After background correction, intensity values of the target of interest were calculated either inside the nuclear or cell area. The image software Fiji was used for image visualization [107]. Brightness and contrast was equally adjusted between images of the same panel to enhance clarity.

\subsection{Quantitative polymerase chain reaction ( $q P C R$ )}

After cell lysis by Trizol (Thermo Fisher), total RNA was isolated using the RNeasy Mini Kit (Qiagen) according to the manufacturer's protocol. Reverse transcription was carried out using an iScript ${ }^{\mathrm{TM}} \mathrm{cDNA}$ synthesis kit (Bio-Rad). Quantitative PCR was performed using the $\mathrm{iQ}^{\mathrm{TM}}$

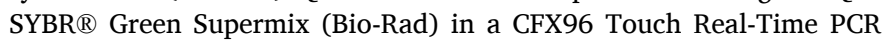
Detection System (Bio-Rad). The software qBase + allowed determining relative expression using the $\Delta \Delta \mathrm{Ct}$ method. The geometric mean of the reference genes Glyceraldehyde 3-phosphate dehydrogenase (GAPDH) and TATA-Box Binding Protein (TBP) was applied for normalization. Primer sequences are listed in Supplementary Table 3.

\subsection{Statistical analysis}

Statistical analysis was performed with GraphPad Prism (GraphPad Prism Software Incl. San Diego, USA). For image analysis where more than two experimental conditions are considered, a two-way ANOVA was applied for determining statistical significance between conditions. Each data point represents a measurement from an individual cell. Image experiments were replicated with similar results. For image analysis with two experimental conditions, such as is the case for the PSMAD data, a two-sided T-test was applied. For qPCR data, two-sided Ttest statistics was applied for determining if the fold change of a condition is significant different than the flat control. One-way ANOVA was applied for determining statistical significance of the fold changes between conditions. qPCR data is based on at least three independent experiments, with each data points representing an independent experiment. Microarray P-values were corrected for multiple testing using the Benjamini and Hochberg method. Genes with a corrected pvalue below 0.05 were considered differentially expressed.

\subsection{MSC osteogenic and adipogenic differentiation}

To assess if the AD-MSCs were multipotent during the experiments, we investigated their potential for differentiation towards the osteogenic and adipogenic lineage. Differentiation of AD-hMSCs towards the osteogenic lineage was achieved by seeding AD-hMSCs at a density of 5 $\times 10^{3}$ cells/cm2. After $24 \mathrm{~h}$, medium was changed with either a control or mineralization medium. The mineralization media is basic media supplemented with $10 \% \mathrm{v} / \mathrm{v}$ fetal bovine serum (FBS), $10 \mathrm{U} / \mathrm{mL}$ Penicillin/Streptomycin, with $10 \mathrm{nM}$ dexamethasone (Sigma) and $10 \mathrm{mM}$ $\beta$-glycerol phosphate (Sigma), while control medium includes the same components except dexamethasone. Media was refreshed every 2-3 days and after 21 days, cells were fixed overnight at $4{ }^{\circ} \mathrm{C}$ with $4 \%$ formaldehyde (VWR) in PBS. Afterwards, osteogenesis was assessed through staining mineralized deposits with a $2 \%$ Alizarin Red solution $(\mathrm{pH}=4.2)$ for $2 \mathrm{~min}$. Excess staining was washed off with demineralized water (Supplementary Fig. 11A).

Differentiation of AD-hMSCs towards the adipogenic lineage was achieved by seeding AD-hMSCs at a density of $15 \times 10^{3}$ cells $/ \mathrm{cm} 2$. After $24 \mathrm{~h}$, medium was replaced with either a control or adipogenic medium. The adipogenic media consist of basic media supplemented with $10 \% \mathrm{v} /$ $\mathrm{v}$ fetal bovine serum (FBS), $10 \mathrm{U} / \mathrm{mL}$ Penicillin/Streptomycin, $0.5 \mathrm{mM} 3-$ isobutyl-1-methylxanthine (Sigma), $0.2 \mathrm{mM}$ indomethacin (Sigma), 10 $\mu \mathrm{g} / \mathrm{mL}$ Insulin (Sigma), and $1 \mu \mathrm{M}$ dexamethasone (Sigma). Control medium consisted solely of basic media with $10 \% \mathrm{v} / \mathrm{v}$ fetal bovine serum (FBS) and $10 \mathrm{U} / \mathrm{mL}$ Penicillin/Streptomycin. Media was refreshed every 2-3 days and after 21 days, cells were fixed overnight at $4{ }^{\circ} \mathrm{C}$ with $3.7 \%$ formaldehyde (VWR), $0.01 \mathrm{~g} / \mathrm{ml} \mathrm{CaCl} 2 \cdot 2 \mathrm{H}_{2} \mathrm{O}$ (Merck) in PBS. Afterwards, adipogenesis was assessed by rinsing the fixation solution with demineralized water, and subsequently incubating the substrates in a 
$60 \%(\mathrm{v} / \mathrm{v})$ 2-propanol (VWR) for $5 \mathrm{~min}$. Fat droplets were stained through a freshly filtered solution of $0.3 \%(\mathrm{w} / \mathrm{v})$ Oil Red O dissolved in $60 \%$ (v/v) 2-propanol (VWR). Afterwards, the substrates were washed in triplicate with demineralized water (Supplementary Fig. 11B).

\section{CRediT authorship contribution statement}

Steven Vermeulen: Conceptualization, Methodology, Software, Formal analysis, Writing - original draft, Investigation, Validation, Visualization. Nadia Roumans: Investigation, Validation. Floris Honig: Investigation, Validation. Aurélie Carlier: Software, Formal analysis. Dennie G.A.J. Hebels: Methodology, Software, Formal analysis, Data curation. Aysegul Dede Eren: Investigation, Validation. Peter ten Dijke: Conceptualization, Writing - review \& editing. Aliaksei Vasilevich: Software, Formal analysis. Jan de Boer: Conceptualization, Supervision, Writing - review \& editing, Project administration, Funding acquisition.

\section{Declaration of competing interest}

The authors declare that they have no known competing financial interests or personal relationships that could have appeared to influence the work reported in this paper.

\section{Acknowledgments}

SV, NR, FH, DH, AD, AC, and JdB acknowledge the financial support of the Dutch province of Limburg. This project has received funding from the European Union's Horizon 2020 research and innovation programme under the Marie Skłodowska-Curie grant agreement No 676338. PtD is supported by the Cancer Genomics Center Netherlands (CGC.NL). AC gratefully acknowledges her VENI grant (number 15057) from the Dutch Science Foundation (NWO). We thank Freek Bouwman, Edwin Mariman, and Midory Thorikay for expert technical assistance.

\section{Appendix A. Supplementary data}

Supplementary data to this article can be found online at https://doi. org/10.1016/j.biomaterials.2020.120331.

\section{Data availability statement}

The raw/processed data required to reproduce these findings are available to download from DataverseNL (https://doi.org/10.348 94/VVATM8).

\section{References}

[1] T. Mammoto, D.E. Ingber, Mechanical control of tissue and organ development, Development 137 (2010) 1407-1420, https://doi.org/10.1242/dev.024166.

[2] D.F. Goldspink, V.M. Cox, S.K. Smith, L.A. Eaves, N.J. Osbaldeston, D.M. Lee, D. Mantle, Muscle growth in response to mechanical stimuli, Am. J. Physiol. Endocrinol. Metab. 268 (1995) 288-297, https://doi.org/10.1152/ ajpendo.1995.268.2.e288.

[3] S. Rosager, P. Aagaard, K. Neergaard, M. Kjaer, S.P. Magnusson, Loaddisplacement properties of the human triceps surae aponeurosis and tendon in runners and non-runners, Scand. J. Med. Sci. Sports 12 (2002) 90-98, https://doi. org/10.1034/j.1600-0838.2002.120205.x.

[4] R.M. Potter, R.T. Huynh, B.D. Volper, K.A. Arthur, A.C. D’Lugos, M.A. Sørensen S. Peter Magnusson, J.M. Dickinson, T.M. Hale, C.C. Carroll, Impact of TGF- $\beta$ inhibition during acute exercise on achilles tendon extracellular matrix, Am. J. Physiol. Regul. Integr. Comp. Physiol. 312 (2017) R157-R164, https://doi.org/ 10.1152/ajpregu.00439.2016.

[5] P.J. Wipff, D.B. Rifkin, J.J. Meister, B. Hinz, Myofibroblast contraction activates latent TGF- $\beta 1$ from the extracellular matrix, J. Cell Biol. 179 (2007) 1311-1323, https://doi.org/10.1083/jcb.200704042.

[6] F. Etoc, J. Metzger, A. Ruzo, C. Kirst, A. Yoney, M.Z. Ozair, A.H. Brivanlou, E. D. Siggia, A balance between secreted inhibitors and edge sensing controls gastruloid self-organization, Dev. Cell 39 (2016) 302-315, https://doi.org/ 10.1016/j.devcel.2016.09.016.
[7] J. Eyckmans, T. Boudou, X. Yu, C.S. Chen, A hitchhiker's guide to mechanobiology, Dev. Cell 21 (2011) 35-47, https://doi.org/10.1016/j. devcel.2011.06.015.

[8] B.W. Benham-Pyle, B.L. Pruitt, W.J. Nelson, Mechanical strain induces Ecadherin-dependent Yap1 and $\beta$-catenin activation to drive cell cycle entry, Science 348 (2015) 1024-1027, https://doi.org/10.1126/science.aaa4559, 80-

[9] M. Aragona, T. Panciera, A. Manfrin, S. Giulitti, F. Michielin, N. Elvassore, S. Dupont, S. Piccolo, A mechanical checkpoint controls multicellular growth through YAP/TAZ regulation by actin-processing factors, Cell 154 (2013) 1047-1059, https://doi.org/10.1016/j.cell.2013.07.042.

[10] J.L. Maître, H. Turlier, R. Illukkumbura, B. Eismann, R. Niwayama, F. Nédélec, T. Hiiragi, Asymmetric division of contractile domains couples cell positioning and fate specification, Nature 536 (2016) 344-348, https://doi.org/10.1038/ nature18958.

[11] A. Elbediwy, Z.I. Vincent-Mistiaen, B. Spencer-Dene, R.K. Stone, S. Boeing, S. K. Wculek, J. Cordero, E.H. Tan, R. Ridgway, V.G. Brunton, E. Sahai, H. Gerhardt, A. Behrens, I. Malanchi, O.J. Sansom, B.J. Thompson, Integrin signalling regulates YAP and TAZ to control skin homeostasis, Dev 143 (2016) 1674-1687, https://doi.org/10.1242/dev.133728.

[12] J. Hong, J. Hong, E.S. Hwang, M.T. McManus, A. Amsterdam, Y. Tian, R. Kalmukova, E. Mueller, T. Benjamin, B.M. Spiegelman, P. a Sharp, N. Hopkins, M.B. Yaffe, J. Hong, E.S. Hwang, M.T. McManus, A. Amsterdam, Y. Tian, R. Kalmukova, E. Mueller, T. Benjamin, B.M. Spiegelman, P. a Sharp, N. Hopkins, M.B. Yaffe, TAZ , a transcriptional modulator of mesenchymal stem cell differentiation, Science 309 (2005) 1074-1078, https://doi.org/10.1126/ science.1110955, 80-.

[13] K.-S. Lee, H.-J. Kim, Q.-L. Li, X.-Z. Chi, C. Ueta, T. Komori, J.M. Wozney, E.G. Kim, J.-Y. Choi, H.-M. Ryoo, S.-C. Bae, Runx2 is a common target of transforming growth factor beta 1 and bone morphogenetic protein 2, and cooperation between Runx2 and Smad5 induces osteoblast-specific gene expression in the pluripotent mesenchymal precursor cell line C2C12, Mol. Cell Biol. 20 (2000) 8783-8792, https://doi.org/10.1128/mcb.20.23.87838792.2000.

[14] A. Sotiropoulos, D. Gineitis, J.W. Copeland, R. Treisman, Signal-regulated activation of serum response factor is mediated by changes in actin dynamics, Cell 98 (1999) 159-169, https://doi.org/10.1016/S0092-8674(00)81011-9.

[15] J.M. Miano, X. Long, K. Fujiwara, Serum response factor: master regulator of the actin cytoskeleton and contractile apparatus, Am. J. Physiol. Cell Physiol. 292 (2007) 70-81, https://doi.org/10.1152/ajpcell.00386.2006.

[16] S. Li, D. Wang, Z. Wang, J.A. Richardson, E.N. Olson, The serum response factor coactivator myocardin is required for vascular smooth muscle development, Proc. Natl. Acad. Sci. Unit. States Am. 100 (2003) 9366-9370, https://doi.org/ 10.1073/pnas.1233635100.

[17] X.H. Zhao, C. Laschinger, P. Arora, K. Szászi, A. Kapus, C.A. McCulloch, Force activates smooth muscle $\alpha$-actin promoter activity through the Rho signaling pathway, J. Cell Sci. 120 (2007) 1801-1809, https://doi.org/10.1242/ jcs.001586.

[18] B. Hu, Z. Wu, S.H. Phan, Smad3 mediates transforming growth factor- $\beta$-induced $\alpha$-smooth muscle actin expression, Am. J. Respir. Cell Mol. Biol. 29 (2003) 397-404, https://doi.org/10.1165/rcmb.2003-00630C.

[19] R. McBeath, D.M. Pirone, C.M. Nelson, K. Bhadriraju, C.S. Chen, Cell shape, cytoskeletal tension, and RhoA regulate stem cell lineage commitment, Dev. Cell 6 (2004) 483-495, https://doi.org/10.1016/S1534-5807(04)00075-9.

[20] K.A. Kilian, B. Bugarija, B.T. Lahn, M. Mrksich, Geometric cues for directing the differentiation of mesenchymal stem cells, Proc. Natl. Acad. Sci. Unit. States Am. 107 (2010) 4872-4877, https://doi.org/10.1073/pnas.0903269107.

[21] G. Abagnale, M. Steger, V.H. Nguyen, N. Hersch, A. Sechi, S. Joussen, B. Denecke, R. Merkel, B. Hoffmann, A. Dreser, U. Schnakenberg, A. Gillner, W. Wagner, Surface topography enhances differentiation of mesenchymal stem cells towards osteogenic and adipogenic lineages, Biomaterials 61 (2015) 316-326, https:// doi.org/10.1016/j.biomaterials.2015.05.030.

[22] A. Mitra, S. Venkatachalapathy, P. Ratna, Y. Wang, D.S. Jokhun, G. V. Shivashankar, Cell geometry dictates TNF $\alpha$-induced genome response, Proc. Natl. Acad. Sci. Unit. States Am. 114 (2017) E3882-E3891, https://doi.org/ 10.1073/pnas.1618007114.

[23] Y. Wang, X. Yu, D.M. Cohen, M.A. Wozniak, M.T. Yang, L. Gao, J. Eyckmans, C. $\mathrm{S}$. Chen, Bone morphogenetic protein-2-induced signaling and osteogenesis is regulated by cell shape, RhoA/ROCK, and cytoskeletal tension, Stem Cell. Dev. 21 (2012) 1176-1186, https://doi.org/10.1089/scd.2011.0293.

[24] J.T. Connelly, J.E. Gautrot, B. Trappmann, D.W.-M. Tan, G. Donati, W.T.S. Huck, F.M. Watt, Actin and serum response factor transduce physical cues from the microenvironment to regulate epidermal stem cell fate decisions, Nat. Cell Biol. 12 (2010) 711-718, https://doi.org/10.1038/ncb2074.

[25] N. Jain, V. Vogel, Spatial confinement downsizes the inflammatory response of macrophages, Nat. Mater. (2018), https://doi.org/10.1038/s41563-018-0190-6.

[26] E. Havis, M.-A. Bonnin, I. Olivera-Martinez, N. Nazaret, M. Ruggiu, J. Weibel, C. Durand, M.-J. Guerquin, C. Bonod-Bidaud, F. Ruggiero, R. Schweitzer, D. Duprez, Transcriptomic analysis of mouse limb tendon cells during development, Development 141 (2014) 3683-3696, https://doi.org/10.1242/ dev.108654.

[27] B. Greber, H. Lehrach, J. Adjaye, Fibroblast growth factor 2 modulates transforming growth factor beta signaling in mouse embryonic fibroblasts and human ESCs (hESCs) to support hESC self-renewal, Stem Cell. 25 (2007) 455-464, https://doi.org/10.1634/stemcells.2006-0476.

[28] H. Iwasaki, S. Eguchi, H. Ueno, F. Marumo, Y. Hirata, Mechanical stretch stimulates growth of vascular smooth muscle cells via epidermal growth factor 
receptor, Am. J. Physiol. Heart Circ. Physiol. 278 (2000) H521-H529, https:// doi.org/10.1152/ajpheart.2000.278.2.H521.

[29] Y. Tanabe, M. Saito, A. Ueno, M. Nakamura, K. Takeishi, K. Nakayama, Mechanical stretch augments PDGF receptor $\beta$ expression and protein tyrosine phosphorylation in pulmonary artery tissue and smooth muscle cells, Mol. Cell. Biochem. 215 (2000) 103-113, https://doi.org/10.1023/A:1026506801659.

[30] M.A. Spassova, D.L. Gill, J. Soboloff, T. Hewavitharana, W. Xu, A common mechanism underlies stretch activation and receptor activation of TRPC6 channels, Proc. Natl. Acad. Sci. Unit. States Am. 103 (2006) 16586-16591, https://doi.org/10.1073/pnas.0606894103.

[31] H. V Unadkat, M. Hulsman, K. Cornelissen, B.J. Papenburg, R.K. Truckenmüller, A.E. Carpenter, M. Wessling, G.F. Post, M. Uetz, M.J. T Reinders, D. Stamatialis, C.A. van Blitterswijk, J. de Boer, B. Robert Langer, An algorithm-based topographical biomaterials library to instruct cell fate, Proc. Natl. Acad. Sci. Unit States Am. 108 (2011) 16565-16570.

[32] P. Eliasson, T. Andersson, M. Hammerman, P. Aspenberg, Primary gene response to mechanical loading in healing rat Achilles tendons, J. Appl. Physiol. 114 (2013) 1519-1526, https://doi.org/10.1152/japplphysiol.01500.2012.

[33] L.D. Belmont, T.J. Mitchison, Identification of a protein that interacts with tubulin dimers and increases the catastrophe rate of microtubules, Cell 84 (1996) 623-631, https://doi.org/10.1016/S0092-8674(00)81037-5.

[34] P.B. Moore, H.E. Huxley, D.J. DeRosier, Three-dimensional reconstruction of Factin, thin filaments and decorated thin filaments, J. Mol. Biol. 50 (1970) 279-296, https://doi.org/10.1016/0022-2836(70)90192-0.

[35] A.J. Ridley, A. Hall, The small GTP-binding protein rho regulates the assembly of focal adhesions and actin stress fibers in response to growth factors, Cell 70 (1992) 389-399, https://doi.org/10.1016/0092-8674(92)90163-7.

[36] A. Gautreau, P. Poullet, D. Louvard, M. Arpin, Ezrin, A plasma membranemicrofilament linker, signals cell survival through the phosphatidylinositol 3-kinase ${ }^{-}$Akt pathway, Proc. Natl. Acad. Sci. Unit. States Am. 96 (1999) 7300-7305, https://doi.org/10.1073/pnas.96.13.7300.

[37] K. Takahashi, T. Sasaki, A. Mammoto, K. Takaishi, T. Kameyama, S. Tsukita, S. Tsukita, Y. Takai, Direct interaction of the Rho GDP dissociation inhibitor with ezrin/radixin/moesin initiates the activation of the Rho small G protein, J. Biol. Chem. 272 (1997) 23371-23375, https://doi.org/10.1074/jbc.272.37.23371.

[38] N. Watanabe, T. Kato, A. Fujita, T. Ishizaki, S. Narumiya, Cooperation between mDia1 and ROCK in Rho-induced actin reorganization, Nat. Cell Biol. 1 (1999) 136-143, https://doi.org/10.1038/11056.

[39] K. Somogyi, P. Rørth, Evidence for tension-based regulation of Drosophila MAL and SRF during invasive cell migration, Dev. Cell 7 (2004) 85-93, https://doi. org/10.1016/j.devcel.2004.05.020.

[40] A.F. Straight, C.M. Field, T.J. Mitchison, Anillin binds nonmuscle myosin II and regulates the contractile ring, Mol. Biol. Cell 16 (2005) 193-201, https://doi.org/ 10.1091/mbc.e04-08-0758.

[41] A.J. Piekny, M. Glotzer, Anillin is a scaffold protein that links RhoA, actin, and myosin during cytokinesis, Curr. Biol. 18 (2008) 30-36, https://doi.org/10.1016/ j.cub.2007.11.068.

[42] S. Vermeulen, A. Vasilevich, D. Tsiapalis, N. Roumans, P. Vroemen, N.R.M. Beijer, A. Dede, D. Zeugolis, J. De Boer, Identification of topographical architectures supporting the phenotype of rat tenocytes, Acta Biomater. 83 (2019) 277-290, https://doi.org/10.1016/j.actbio.2018.10.041.

[43] K. Baek, X. Liu, F. Ferron, S. Shu, E.D. Korn, R. Dominguez, Modulation of actin structure and function by phosphorylation of Tyr-53 and profilin binding, Proc. Natl. Acad. Sci. U.S.A. 105 (2008) 11748-11753, https://doi.org/10.1073/ pnas.0805852105.

[44] E.A. Papakonstanti, C. Strournaras, Association of PI-3 kinase with PAK1 leads to actin phosphorylation and cytoskeletal reorganization, Mol. Biol. Cell 13 (2002) 2946-2962, https://doi.org/10.1091/mbc.02-01-0599.

[45] K. Moriyama, I. Yahara, Human CAP1 is a key factor in the recycling of cofilin and actin for rapid actin turnover, J. Cell Sci. 115 (2002) 1591-1601.

[46] S. Sharma, E.E. Grintsevich, M.L. Phillips, E. Reisler, J.K. Gimzewski, Atomic force microscopy reveals drebrin induced remodeling of F-actin with subnanometer resolution, Nano Lett. 11 (2011) 825-827, https://doi.org/ $10.1021 / \mathrm{nl} 104159 \mathrm{v}$.

[47] R. Treisman, Identification of a protein-binding site that mediates transcriptional response of the c-fos gene to serum factors, Cell 46 (1986) 567-574, https://doi. org/10.1016/0092-8674(86)90882-2.

48] G. Schratt, B. Weinhold, a.S. Lundberg, S. Schuck, J. Berger, H. Schwarz, R. a. Weinberg, U. Ruther, A. Nordheim, Serum response factor is required for immediate-early gene activation yet is dispensable for proliferation of embryonic stem cells, Mol. Cell Biol. 21 (2001) 2933, https://doi.org/10.1128/ MCB.21.8.2933.

[49] V. Lejard, F. Blais, M.J. Guerquin, A. Bonnet, M.A. Bonnin, E. Havis, M. Malbouyres, C.B. Bidaud, G. Maro, P. Gilardi-Hebenstreit, J. Rossert, F. Ruggiero, D. Duprez, EGR1 and EGR2 involvement in vertebrate tendon differentiation, J. Biol. Chem. 286 (2011) 5855-5867, https://doi.org/10.1074/ jbc.M110.153106.

[50] M.J. Guerquin, B. Charvet, G. Nourissat, E. Havis, O. Ronsin, M.A. Bonnin, M. Ruggiu, I. Olivera-Martinez, N. Robert, Y. Lu, K.E. Kadler, T. Baumberger, L. Doursounian, F. Berenbaum, D. Duprez, Transcription factor EGR1 directs tendon differentiation and promotes tendon repair, J. Clin. Invest. 123 (2013) 3564-3576, https://doi.org/10.1172/JCI67521.

[51] L. Gaut, N. Robert, A. Delalande, M.A. Bonnin, C. Pichon, D. Duprez, EGR1 regulates transcription downstream of mechanical signals during tendon formation and healing, PloS One 11 (2016) 1-16, https://doi.org/10.1371/ journal.pone.0166237.
[52] P.J. Wilder, C.T. Bernadt, J.-H. Kim, A. Rizzino, Stimulation of the murine type II transforming growth factor-beta receptor promoter by the transcription factor Egr-1, Mol. Reprod. Dev. 63 (2002) 282-290, https://doi.org/10.1002/ mrd.10165.

53] Y. Zhang, X.-H. Feng, R. Derynck, Smad3 and Smad4 cooperate with c-Jun/c-Fos to mediate TFG-b-induced transcription, Nature 394 (1998) 909-913, https://doi. org/10.1038/29814.

[54] A. Fine, R.H. Goldstein, The effect of transforming growth factor- $\beta$ on cell proliferation and collagen formation by lung fibroblasts, J. Biol. Chem. 262 (1987) 3897-3902.

[55] E.B. Brunschwig, K. Wilson, D. Mack, D. Dawson, E. Lawrence, J.K.V. Willson, S, L. Lu, A. Nosrati, R.M. Rerko, S. Swinler, L. Beard, J.D. Lutterbaugh, J. Willis, P. Platzer, S. Markowitz, PMEPA1, a transforming growth factor- $\beta$-induced marker of terminal colonocyte differentiation whose expression is maintained in primary and metastatic colon cancer, Canc. Res. 63 (2003) 1568-1575.

[56] J. Poveda, A.B. Sanz, B. Fernandez-Fernandez, S. Carrasco, M. Ruiz-Ortega, P. Cannata-Ortiz, A. Ortiz, M.D. Sanchez-Niño, MXRA5 is a TGF- $\beta 1$-regulated human protein with anti-inflammatory and anti-fibrotic properties, J. Cell Mol. Med. 21 (2017) 154-164, https://doi.org/10.1111/jcmm.12953.

[57] S. Paliwal, J. Shi, U. Dhru, Y. Zhou, L. Schuger, P311 binds to the latency associated protein and downregulates the expression of TGF- $\beta 1$ and TGF- $\beta 2$, Biochem. Biophys. Res. Commun. 315 (2004) 1104-1109, https://doi.org/ 10.1016/j.bbrc.2004.01.171.

[58] M. Stopa, D. Anhuf, L. Terstegen, P. Gatsios, A.M. Gressner, S. Dooley, Participation of Smad2, Smad3, and Smad4 in transforming growth factor B ( TGF-B)-induced activation of Smad7, J. Biol. Chem. 275 (2000) 29308-29317, https://doi.org/10.1074/jbc.M003282200.

[59] M. Agassandian, J.R. Tedrow, J. Sembrat, D.J. Kass, Y. Zhang, E.A. Goncharova, N. Kaminski, R.K. Mallampalli, L.J. Vuga, VCAM-1 is a TGF- $\beta 1$ inducible gene upregulated in idiopathic pulmonary fibrosis, Cell. Signal. 27 (2015) 2467-2473, https://doi.org/10.1016/j.cellsig.2015.09.003.

[60] N. Jones, F.H. Agani, Hyperoxia induces Egr-1 expression through activation of extracellular signal-regulated kinase 1/2 pathway, J. Cell. Physiol. 196 (2003) 326-333, https://doi.org/10.1002/jcp.10308.

[61] M.M.M. Abdel-Latif, H.J. Windle, A. Davies, Y. Volkov, D. Kelleher, A new mechanism of gastric epithelial injury induced by acid exposure: the role of Egr-1 and ERK signaling pathways, J. Cell. Biochem. 108 (2009) 249-260, https://doi. org/10.1002/jcb.22247.

[62] O. Skalli, P. Ropraz, A. Trzeciak, G. Benzonana, D. Gillessen, G. Gabbiani, A monoclonal antibody against $\alpha$-smooth muscle actin: a new probe for smooth muscle differentiation, J. Cell Biol. 103 (1986) 2787-2796, https://doi.org/ 10.1083/jcb.103.6.2787.

[63] W. Bi, J.M. Deng, Z. Zhang, R.R. Behringer, B. De Crombrugghe, Sox9 is required for cartilage formation, Nat. Genet. 22 (1999) 85-89, https://doi.org/10.1038/ 8792.

[64] G.J. Inman, F.J. Nicolás, J.F. Callahan, J.D. Harling, L.M. Gaster, A.D. Reith, N. J. Laping, C.S. Hill, SB-431542 is a potent and specific inhibitor of transforming growth factor- $\beta$ superfamily type I activin receptor-like kinase (ALK) receptors ALK4, ALK5, and ALK7, Mol. Pharmacol. 62 (2002) 65-74, https://doi.org/ 10.1124/mol.62.1.65.

[65] S.T. Sit, E. Manser, Rho GTPases and their role in organizing the actin cytoskeleton, J. Cell Sci. 124 (2011) 679-683, https://doi.org/10.1242/ jcs.064964.

[66] K. Hutchings, E.M. Lisabeth, W. Rajeswaran, M.W. Wilson, R.J. Sorenson, P. Campbell, J.H. Ruth, A. Amin, P.-S. Tsou, J.R. Leipprandt, S.R. Olson, B. Wen, T. Zhao, D. Sun, D. Khanna, D.A. Fox, R.R. Neubig, S.D. Larsen, Pharmacokinetic optimization of CCG-203971: novel inhibitors of the rho/MRTF/SRF transcriptional pathway as potential antifibrotic therapeutics for systemic scleroderma, Bioorg. Med. Chem. Lett 27 (2017) 1744-1749, https://doi.org/ 10.1016/j.bmcl.2017.02.070.

[67] J. Limouze, A.F. Straight, T. Mitchison, J.R. Sellers, Specificity of blebbistatin, an inhibitor of myosin II, J. Muscle Res. Cell Motil. 25 (2004) 337-341, https://doi. org/10.1007/s10974-004-6060-7.

[68] K. Murthy, P. Wadsworth, Myosin-II-dependent localization and dynamics of Factin during cytokinesis, Curr. Biol. 15 (2005) 724-731, https://doi.org/ 10.1016/j.cub.2005.02.055.

[69] A. Subramanian, R. Narayan, S.M. Corsello, D.D. Peck, T.E. Natoli, X. Lu, J. Gould, J.F. Davis, A.A. Tubelli, J.K. Asiedu, D.L. Lahr, J.E. Hirschman, Z. Liu, M. Donahue, B. Julian, M. Khan, D. Wadden, I.C. Smith, D. Lam, A. Liberzon, C. Toder, M. Bagul, M. Orzechowski, O.M. Enache, F. Piccioni, S.A. Johnson, N. J. Lyons, A.H. Berger, A.F. Shamji, A.N. Brooks, A. Vrcic, C. Flynn, J. Rosains, D. Y. Takeda, R. Hu, D. Davison, J. Lamb, K. Ardlie, L. Hogstrom, P. Greenside, N. S. Gray, P.A. Clemons, S. Silver, X. Wu, W.N. Zhao, W. Read-Button, X. Wu, S. J. Haggarty, L.V. Ronco, J.S. Boehm, S.L. Schreiber, J.G. Doench, J.A. Bittker, D. E. Root, B. Wong, T.R. Golub, A next generation connectivity map: L1000 platform and the first 1,000,000 profiles, Cell 171 (2017) 1437-1452, https:// doi.org/10.1016/j.cell.2017.10.049, e17.

[70] C. Larsson, Protein kinase $\mathrm{C}$ and the regulation of the actin cytoskeleton, Cell. Signal. 18 (2006) 276-284, https://doi.org/10.1016/j.cellsig.2005.07.010.

[71] M. Schliwa, T. Nakamura, K.R. Porter, U. Euteneuer, A tumor promoter induces rapid and coordinated reorganization of actin and vinculin in cultured cells, J. Cell Biol. 99 (1984) 1045-1059, https://doi.org/10.1083/jcb.99.3.1045.

[72] J.-W. Soh, E.H. Lee, R. Prywes, I.B. Weinstein, Novel roles of specific isoforms of protein kinase $\mathrm{C}$ in activation of the c- fos serum response element, Mol. Cell Biol. 19 (1999) 1313-1324, https://doi.org/10.1128/mcb.19.2.1313. 
[73] L.M. Halvorson, U.B. Kaiser, W.W. Chin, The protein kinase C system acts through the early growth response protein 1 to increase LH $\beta$ gene expression in synergy with steroidogenic factor-1, Mol. Endocrinol. 13 (1999) 106-116, https://doi. org/10.1210/me.13.1.106.

[74] A.D. Mazzocca, D. Chowaniec, M.B. McCarthy, K. Beitzel, M.P. Cote, W. McKinnon, R. Arciero, In vitro changes in human tenocyte cultures obtained from proximal biceps tendon: multiple passages result in changes in routine cell markers, Knee Surgery, Sport, Traumatol. Arthrosc. 20 (2012) 1666-1672, https://doi.org/10.1007/s00167-011-1711-x.

[75] L.B.E. Shields, G.H. Raque, S.D. Glassman, M. Campbell, T. Vitaz, J. Harpring, C. B. Shields, Adverse effects associated with high-dose recombinant human bone morphogenetic protein-2 use in anterior cervical spine fusion, Spine (Phila. Pa. 31 (1976) 542-547, https://doi.org/10.1097/01.brs.0000201424.27509.72, 2006.

[76] C. Schwarz, D. Wulsten, A. Ellinghaus, J. Lienau, B.M. Willie, G.N. Duda, Mechanical load modulates the stimulatory effect of BMP2 in a rat nonunion model, Tissue Eng. 19 (2013) 247-254, https://doi.org/10.1089/ten. tea.2012.0265.

[77] S.M. Weis, D.A. Cheresh, Pathophysiological consequences of VEGF-induced vascular permeability, Nature 437 (2005) 497-504, https://doi.org/10.1038/ nature03987.

[78] J. Zhu, J. Li, B. Wang, W.J. Zhang, G. Zhou, Y. Cao, W. Liu, The regulation of phenotype of cultured tenocytes by microgrooved surface structure, Biomaterials 31 (2010) 6952-6958, https://doi.org/10.1016/j.biomaterials.2010.05.058.

[79] A. Kapoor, E.H.G. Caporali, P.J.A. Kenis, M.C. Stewart, Microtopographically patterned surfaces promote the alignment of tenocytes and extracellular collagen, Acta Biomater. 6 (2010) 2580-2589, https://doi.org/10.1016/j. actbio.2009.12.047.

[80] A. English, A. Azeem, K. Spanoudes, E. Jones, B. Tripathi, N. Basu, K. McNamara, S.A.M. Tofail, N. Rooney, G. Riley, A. O'Riordan, G. Cross, D. Hutmacher, M. Biggs, A. Pandit, D.I. Zeugolis, Substrate topography: a valuable in vitro tool, but a clinical red herring for in vivo tenogenesis, Acta Biomater. 27 (2015) 3-12, https://doi.org/10.1016/j.actbio.2015.08.035.

[81] W.Y. Tong, W. Shen, C.W.F. Yeung, Y. Zhao, S.H. Cheng, P.K. Chu, D. Chan, G.C F. Chan, K.M.C. Cheung, K.W.K. Yeung, Y.W. Lam, Functional replication of the tendon tissue microenvironment by a bioimprinted substrate and the support of tenocytic differentiation of mesenchymal stem cells, Biomaterials 33 (2012) 7686-7698, https://doi.org/10.1016/j.biomaterials.2012.07.002.

[82] K. Zhou, B. Feng, W. Wang, W. Zhang, G. Zhou, Nanoscaled and microscaled parallel topography promotes tenogenic differentiation of ASC and neotendon formation in vitro, Int. J. Nanomed. (2018) 3867-3881.

[83] W. Wang, J. Li, K. Wang, Z. Zhang, W. Zhang, G. Zhou, Y. Cao, M. Ye, H. Zou, W. Liu, Induction of predominant tenogenic phenotype in human dermal fibroblasts via synergistic effect of TGF- $\beta$, and elongated cell shape, Am. J. Physiol. Cell Physiol. 310 (2015) C357-C372, https://doi.org/10.1152/ ajpcell.00300.2015.

[84] Z. Yin, X. Chen, J.L. Chen, W.L. Shen, T.M. Hieu Nguyen, L. Gao, H.W. Ouyang, The regulation of tendon stem cell differentiation by the alignment of nanofibers, Biomaterials 31 (2010) 2163-2175, https://doi.org/10.1016/j. biomaterials.2009.11.083.

[85] J.G. Barber, A.M. Handorf, T.J. Allee, W.J. Li, Braided nanofibrous scaffold for tendon and ligament tissue engineering, Tissue Eng. 19 (2013) 1265-1274, https://doi.org/10.1089/ten.tea.2010.0538.

[86] R.I. Sharma, J.G. Snedeker, Biochemical and biomechanical gradients for directed bone marrow stromal cell differentiation toward tendon and bone, Biomaterials 31 (2010) 7695-7704, https://doi.org/10.1016/j.biomaterials.2010.06.046.

[87] J.S. Park, J.S. Chu, A.D. Tsou, R. Diop, A. Wang, S. Li, The effect of matrix stiffness on the differentiation of mesenchymal stem cells in response to TGF- $\beta$, Biomaterials 32 (2012) 3921-3930, https://doi.org/10.1016/j. biomaterials.2011.02.019.

[88] J.L. Leight, M.A. Wozniak, S. Chen, M.L. Lynch, C.S. Chen, Matrix rigidity regulates a switch between TGF-B1-induced apoptosis and epithelialmesenchymal transition, Mol. Biol. Cell 23 (2012) 781-791, https://doi.org/ 10.1091/mbc.e11-06-0537.

[89] J.L. Allen, M.E. Cooke, T. Alliston, ECM stiffness primes the TGFB pathway to promote chondrocyte differentiation, Mol. Biol. Cell 23 (2012) 3731-3742, https://doi.org/10.1091/mbc.e12-03-0172.

[90] L. Prodanov, J. te Riet, E. Lamers, M. Domanski, R. Luttge, J.J.W.A. van Loon, J. A. Jansen, X.F. Walboomers, The interaction between nanoscale surface features and mechanical loading and its effect on osteoblast-like cells behavior, Biomaterials 31 (2010) 7758-7765, https://doi.org/10.1016/j. biomaterials.2010.06.050.

[91] X. Shi, L. Li, S. Ostrovidov, Y. Shu, A. Khademhosseini, H. Wu, Stretchable and micropatterned membrane for osteogenic differentation of stem cells, ACS Appl. Mater. Interfaces 6 (2014) 11915-11923, https://doi.org/10.1021/am5029236.

[92] Y. Morita, S. Watanabe, Y. Ju, B. Xu, Determination of optimal cyclic Uniaxial stretches for stem cell-to-tenocyte differentiation under a wide range of mechanical stretch conditions by evaluating gene expression and protein synthesis levels, Acta Bioeng. Biomech. 15 (2013) 71-79, https://doi.org/ $10.5277 / \mathrm{abb} 130309$.

[93] W.K. Grier, A.S. Moy, B.A.C. Harley, Cyclic tensile strain enhances human mesenchymal stem cell SMAD 2/3 activation and tenogenic differentiation in anisotropic collagen-glycosaminoglycan scaffolds, Eur. Cell. Mater. 33 (2017) 227-239, https://doi.org/10.22203/eCM.v033a17.

[94] C.K. Kuo, R.S. Tuan, Mechanoactive tenogenic differentiation of human mesenchymal stem cells, Tissue Eng. 14 (2008) 1615-1627, https://doi.org/ 10.1089/ten.tea.2006.0415.

[95] E. Huisman, A. Lu, R.G. McCormack, A. Scott, Enhanced collagen type i synthesis by human tenocytes subjected to periodic in vitro mechanical stimulation, BMC Muscoskel. Disord. 15 (2014) 1, https://doi.org/10.1186/1471-2474-15-386.

[96] T. Maeda, T. Sakabe, A. Sunaga, K. Sakai, A.L. Rivera, D.R. Keene, T. Sasaki, E. Stavnezer, J. Iannotti, R. Schweitzer, D. Ilic, H. Baskaran, Conversion of mechanical force into TGF-b-mediated biochemical signals, Curr. Biol. 21 (2011) 933-941, https://doi.org/10.1016/j.cub.2011.04.007.

[97] T. Furumatsu, E. Matsumoto, T. Kanazawa, M. Fujii, Z. Lu, R. Kajiki, T. Ozaki, Tensile strain increases expression of CCN2 and COL2A1 by activating TGF$\beta$-Smad2/3 pathway in chondrocytic cells, J. Biomech. 46 (2013) 1508-1515, https://doi.org/10.1016/j.jbiomech.2013.03.028.

[98] K. Kuwahara, T. Barrientos, G.C.T. Pipes, S. Li, E.N. Olson, Muscle-specific signaling mechanism that links actin dynamics to serum response factor, Mol. Cell Biol. 25 (2005) 3173-3181, https://doi.org/10.1128/mcb.25.8.3173-3181.2005.

[99] C.H. Tsai-Morris, X. Cao, V.P. Sukhatme, 5' flanking sequence and genomic structure of egr-1, a murine mitogen inducible zinc finger encoding gene, Nucleic Acids Res. 16 (1988) 8835-8846, https://doi.org/10.1093/nar/16.18.8835.

[100] B. Xu, G. Song, Y. Ju, X. Li, Y. Song, S. Watanabe, RhoA/ROCK, cytoskeletal dynamics, and focal adhesion kinase are required for mechanical stretch-induced tenogenic differentiation of human mesenchymal stem cells, J. Cell. Physiol. 227 (2012) 2722-2729, https://doi.org/10.1002/jcp.23016.

[101] J. Wang, J. Fan, C. Laschinger, P.D. Arora, A. Kapus, A. Seth, C.A. McCulloch, Smooth muscle actin determines mechanical force-induced p38 activation, J. Biol. Chem. 280 (2005) 7273-7284, https://doi.org/10.1074/jbc.M410819200.

[102] L.A. Johnson, E.S. Rodansky, A.J. Haak, S.D. Larsen, R.R. Neubig, P.D.R. Higgins, Novel rho/MRTF/SRF inhibitors block matrix-stiffness and TGF- $\beta$-induced fibrogenesis in human colonic myofibroblasts, Inflamm. Bowel Dis. 20 (2014) 154-165, https://doi.org/10.1097/01.MIB.0000437615.98881.31.

[103] F. Gualdrini, C. Esnault, S. Horswell, A. Stewart, N. Matthews, R. Treisman, SRF Co-factors control the balance between cell proliferation and contractility, Mol. Cell. 64 (2016) 1048-1061, https://doi.org/10.1016/j.molcel.2016.10.016.

[104] M. Wesner, T. Defreitas, H. Bredy, L. Pothier, Z. Qin, A.B. Mckillop, D.P. Gross, A pilot study evaluating the effectiveness of platelet-rich plasma therapy for treating degenerative tendinopathies: a randomized control trial with synchronous observational cohort setting, PloS One (2016), https://doi.org/ 10.1371/journal.pone.0147842.

[105] Y. Zhao, R. Truckenmuller, M. Levers, W.S. Hua, J. de Boer, B. Papenburg, Highdefinition micropatterning method for hard, stiff and brittle polymers, Mater. Sci. Eng. C 71 (2017) 558-564, https://doi.org/10.1016/j.msec.2016.11.004.

[106] C. McQuin, A. Goodman, V. Chernyshev, L. Kamentsky, B.A. Cimini, K. W. Karhohs, M. Doan, L. Ding, S.M. Rafelski, D. Thirstrup, W. Wiegraebe, S. Singh, T. Becker, J.C. Caicedo, A.E. Carpenter, CellProfiler 3.0: next-generation image processing for biology, PLoS Biol. 16 (2018) 1-17, https://doi.org/ 10.1371/journal.pbio.2005970.

[107] J. Schindelin, I. Arganda-Carrera, E. Frise, K. Verena, L. Mark, P. Tobias, P. Stephan, R. Curtis, S. Stephan, S. Benjamin, T. Jean-Yves, J.W. Daniel, H. Volker, E. Kevin, T. Pavel, C. Albert, Fiji - an Open platform for biological image analysis, Nat. Methods 9 (2009) 241, https://doi.org/10.1038/ nmeth.2019.Fiji. 